\title{
Evaluation and improvement of the Community Land Model (CLM4) in Oregon forests
}

\author{
T. W. Hudiburg ${ }^{1}$, B. E. Law ${ }^{2}$, and P. E. Thornton ${ }^{3}$ \\ ${ }^{1} 1206$ W Gregory Drive, Department of Plant Biology, University of Illinois at Urbana-Champaign, Urbana, IL 61801 USA \\ ${ }^{2} 321$ Richardson Hall, Department of Forest Ecosystems and Society, Oregon State University, Corvallis, OR 97331, USA \\ ${ }^{3}$ Oak Ridge National Laboratory, Climate and Ecosystem Processes Environmental Sciences Division, P.O. Box 2008, Oak \\ Ridge, TN 37831-6301, USA
}

Correspondence to: T. W. Hudiburg (hudiburg@illinois.edu), B. E. Law (bev.law @oregonstate.edu) and

P. E. Thornton (thorntonpe@ornl.gov)

Received: 24 August 2012 - Published in Biogeosciences Discuss.: 18 September 2012

Revised: 18 December 2012 - Accepted: 19 December 2012 - Published: 24 January 2013

\begin{abstract}
Ecosystem process models are important tools for determining the interactive effects of global change and disturbance on forest carbon dynamics. Here we evaluated and improved terrestrial carbon cycling simulated by the Community Land Model (CLM4), the land model portion of the Community Earth System Model (CESM1.0.4). Our analysis was conducted primarily in Oregon forests using FLUXNET and forest inventory data for the period 2001-2006. We go beyond prior modeling studies in the region by incorporating regional variation in physiological parameters from $>100$ independent field sites in the region. We also compare spatial patterns of simulated forest carbon stocks and net primary production (NPP) at $15 \mathrm{~km}$ resolution using data collected from federal forest inventory plots (FIA) from $>3000$ plots in the study region. Finally, we evaluate simulated gross primary production (GPP) with FLUXNET eddy covariance tower data at wet and dry sites in the region. We improved model estimates by making modifications to CLM4 to allow physiological parameters (e.g., foliage carbon to nitrogen ratios and specific leaf area), mortality rate, biological nitrogen fixation, and wood allocation to vary spatially by plant functional type (PFT) within an ecoregion based on field plot data in the region. Prior to modifications, default parameters resulted in underestimation of stem biomass in all forested ecoregions except the Blue Mountains and annual NPP was both over- and underestimated. After modifications, model estimates of mean NPP fell within the observed range of uncertainty in all ecoregions (two-sided $P$ value $=0.8$ ), and the underestimation of stem biomass was reduced. This was
\end{abstract}

an improvement from the default configuration by $50 \%$ for stem biomass and $30 \%$ for NPP. At the tower sites, modeled monthly GPP fell within the observed range of uncertainty at both sites for the majority of the year, however summer GPP was underestimated at the Metolius semi-arid pine site and spring GPP was overestimated at the Campbell River mesic Douglas-fir site, indicating GPP may be an area for further improvement. The low bias in summer maximum GPP at the semi-arid site could be due to seasonal response of $V_{\text {cmax }}$ to temperature and precipitation while overestimated spring values at the mesic site could be due to response of $V_{\text {cmax }}$ to temperature and day length.

\section{Introduction}

Modeling and understanding the response of terrestrial ecosystems to changing environmental conditions and land use change are primary goals of climate mitigation policy (IPCC, 2007; Moss et al., 2010; NRC, 2010a; Pacala, 2010). The Intergovernmental Panel for Climate Change (IPCC) synthesizes estimates of future climate change impacts on terrestrial carbon cycling through the use of a specific set of global circulation models (IPCC, 2007). Among them is the Community Earth System Model (CESM) of the National Center for Atmospheric Research (NCAR). The land model component (Community Land Model; CLM4) has been extensively used to evaluate and predict the net carbon uptake 
and loss from terrestrial biomes, particularly forests (Thornton and Zimmermann, 2007; Bonan et al., 2012).

Recent assessments of seasonal performance of multiple terrestrial biosphere models indicated better performance in forest ecosystems, particularly in evergreen forests, during the summer growing season than in other biomes and seasons (Schwalm et al., 2010). The highest skill across biomes was in models that prescribed canopy phenology and did not use a daily time step (Schwalm et al., 2010). In an assessment with FLUXNET tower data, Schaefer et al. (2013) found that none of the models estimated gross photosynthesis (GPP) at all sites within observed uncertainty. The most important factor influencing model performance was light-use efficiency computed from the slope of the GPP-light response curve. This is influenced by photosynthetic parameters, indicating better parameter values are needed for variables influencing light use efficiency (LUE). The model evaluations also suggested more detailed assessments need to be performed with individual models. The photosynthesis model of Farquhar et al. (1980) is widely used in vegetation models, and an evaluation at more than 200 FLUXNET sites showed that simple plant functional type (PFT) classification of photosynthesis parameters introduces uncertainty in photosynthesis and transpiration fluxes (Groenendijk et al., 2012b), and including $V_{\text {cmax }}$ seasonality can improve predictions (Groenendijk et al., 2012a). The study suggested focusing on the effects of seasonal foliar nitrogen on $V_{\text {cmax }}$. In an assessment of CLM4 with FLUXNET data, Bonan et al. (2011) also found that the bias in annual GPP could be reduced by including improved estimates of photosynthetic parameters. Finally, CLM4 was also found to overestimate shade-leaf photosynthesis leading to overestimation of canopy GPP when the nitrogen limitation functionality was inactive (Bonan et al., 2012), suggesting a multi-layer canopy could improve initial GPP calculations before downregulation due to nitrogen limitation is imposed.

In this paper, we evaluate the Community Land Model (version 4.0) portion of the Community Earth System Model (CESM1.0.4). CLM4 is the latest in a series of land models developed for the CESM and runs at a half-hourly time step. CLM4 includes coupled carbon and nitrogen processes and examines the physical, chemical, and biological processes through which terrestrial ecosystems affect and are affected by climate across a variety of spatial and temporal scales. Recent model releases include improvements to hydrology and an integrated transient land cover and land use change dataset (Lawrence et al., 2011a). The transient land cover dataset includes historical wood harvest which is known to have a large influence on Pacific Northwest forest carbon storage and uptake (Harmon et al., 1990; Law et al., 2004). When the carbon-nitrogen biogeochemistry is active, CLM4 uses prognostic canopy phenology to determine leaf and stem area indexes (LAI and SAI) and vegetation height. Potential GPP is calculated from leaf photosynthetic rate without nitrogen constraint. Actual GPP is computed from nitrogen limitations to potential GPP.

Our objective was to evaluate carbon stocks and fluxes simulated by CLM4 in a representative sample of Pacific Northwest forests using independent datasets with different spatial and temporal resolutions, rather than relying only on a few eddy covariance tower sites as is typical. We utilized annual carbon stocks and net primary production (NPP) computed from over 3000 forest inventory plots that had been scaled to the study region with remote sensing data to produce a spatial dataset (Hudiburg et al., 2011; Law et al., 2012), and the seasonal data were gross photosynthesis from two FLUXNET sites in the region (Krishnan et al., 2009; Thomas et al., 2009). Model evaluation with an observationbased spatially representative dataset such as federal forest inventory (FIA) data is critical in order to constrain model estimates, facilitate model development and ultimately reduce model uncertainty. Reduced model uncertainty is beneficial for forest policy development of land use practices aimed at increasing carbon sequestration. Combined with seasonal data and analysis over a strong climatic gradient, diagnostics can point to areas for model improvements. The specific objectives of this study are to (1) evaluate regional model performance against spatially representative FIA estimates of stem wood biomass and annual NPP; (2) evaluate seasonal model performance against monthly tower GPP utilizing observed physiological parameters; and (3) examine the roles of modeled LUE, temperature, precipitation, and nitrogen limitation in determining seasonal patterns of GPP. Temperature is a dominant control on the seasonal variation in GPP (Schaefer et al., 2013), whereas nitrogen and water limitation are major determinants of seasonal maximum GPP (Lawrence et al., 2011b; Bonan et al., 2011).

The accuracy and uncertainty associated with regional estimates of carbon fluxes by CLM4 is unknown because model output is not usually validated against spatially representative observations. The federal forest inventory (FIA) collects data on an annual basis on all forestland regardless of ownership or location, resulting in an intensively sampled landscape through which modeled estimates of forest carbon stocks and fluxes could be evaluated. FIA data provide measurements that can be used to calculate the carbon density of live and dead trees, woody detritus, and understory shrubs. Wood increment data are also provided, allowing estimation of 5-10 yr average bole wood production, depending on the repeat measurement cycle. Combined with remote sensing land cover products, reliable maps of wood carbon stocks, net primary production, heterotrophic respiration $\left(R_{\mathrm{h}}\right)$, and net ecosystem production (NEP) can be produced (Hudiburg et al., 2011) to validate model output and identify model biases. The associated uncertainty in the FIA estimates can also be calculated, providing a range of values or baseline conditions modeling activities should be constrained by before making predictions about future conditions. 
Here, we evaluate CLM4 with FIA data maps of wood carbon stocks and NPP averaged for the years 2001-2006 in Oregon forests. We improve on model estimates by calibrating with supplemental plot data collected at over 100 sites across the study area. The region is characterized by tremendous climate variation (Table 1), and it has been recommended that a minimum of $15 \mathrm{~km}$ resolution be utilized in such heterogeneous terrain (Salathé et al., 2010). We utilize a new downscaled $200 \mathrm{yr} 1 / 8$ th degree $(15 \mathrm{~km})$ resolution dataset specifically designed for use in the Pacific Northwest (Salathe et al., 2007). Furthermore, we also test the model's ability to determine the seasonal timing and magnitude of GPP by comparing modeled estimates with eddy covariance data in the region, and evaluate tower annual NPP and GPP for consistency (Luyssaert et al., 2009). Finally, we make modifications to model algorithms and plant functional type physiological parameterization to improve model performance. By using existing datasets and uncertainty quantification, this research provides a solid scientific foundation for evaluating carbon dynamics under conditions of future climate change and land management practices at local and regional scales.

\section{Methods}

\subsection{Model description}

The model used to simulate these processes is the Community Land Model (CLM version 4.0) portion of the Community Earth System Model (CESM1.0.4) of the National Center for Atmospheric Research (Oleson et al., 2010). CLM4 uses hourly climate data, ecophysiological characteristics, site physical characteristics, and site history to estimate the daily fluxes of carbon, nitrogen, and water between the atmosphere, plant state variables, and litter and soil state variables. State variables are the live and dead carbon pools. CLM4 examines the physical, chemical, and biological processes through which terrestrial ecosystems affect and are affected by climate across a variety of spatial and temporal scales. The basic assumption is that terrestrial ecosystems, through their cycling of energy, water, chemical elements, and trace gases, are important determinants of climate. Model components consist of biogeophysics, hydrologic cycle, biogeochemistry and dynamic vegetation. The land surface is divided into five sub-grid land cover types (glacier, lake, wetland, urban, vegetated) in each grid cell. The vegetated portion of a grid cell is further divided into patches of plant functional types, each with its own leaf and stem area index and canopy height. The multiple PFTs within the grid cell compete for water and nutrients on a single soil column.

Recent model improvements include updates to hydrology and an integrated transient land cover and land use change dataset that accounts for wood harvest. Updates to the hydrology include improved ground evaporation parameteri- zation and snowpack heating and aging resulting in higher snow cover, cooler soil temperatures in organic-rich soils, greater river discharge, and lower albedos over forests and grasslands (Lawrence et al., 2011a). The transient land use dataset has been formatted for use by CLM4 from a global historical transient land use and land cover change dataset (Hurtt et al., 2006) covering the period from 1850-2005. The dataset describes land cover and its change via four classes of vegetation (crop, pasture, primary vegetation, and secondary vegetation). The dataset also describes the annual fraction of land that is transformed from one PFT to another including the conversion of primary forest to secondary forest, which is essential for studies attempting to track forest carbon storage and uptake over time. This dataset essentially provides a human-induced disturbance history of forests which can be used to test the model's ability to simulate carbon dynamics following harvest.

\subsection{Model calibration and forcing datasets}

CLM4 has over 40 physiological parameters for each of the 17 plant functional types and a default constant mortality rate of $2 \%$ for all PFTs. The PFTs include 8 different forested and 3 different shrub land PFTs (Appendix A; Tables A1 and A2). We use data collected on 100 supplemental plots located throughout the study region (Fig. 1) to calibrate the physiology parameters, mortality rate, and wood allocation algorithms. Default physiology values were used for parameters where data was unavailable and for parameters which are known to have little influence on biomass and NPP. Assessment and sensitivity analysis of CLM4 to the parameter values has been tested and described (White et al., 2000; Lawrence et al., 2011a), and we incorporate this knowledge to facilitate our regional calibration. The supplemental plot dataset includes measurements of specific leaf area (SLA; projected), foliar carbon nitrogen ratios, litter carbon nitrogen ratios, and leaf longevity for the major tree species across the study region. We use the PFT mean for each of these parameters in the calibrated physiology file for default model configuration evaluation, hereafter indicated as "CLM4" in figures and text. Prior modeling studies in this region indicate that a dynamic mortality rate that varies with age and/or disturbance type is necessary to predict the correct seasonal and annual carbon fluxes (Turner et al., 2007), especially in the drier forest types where mortality decreases as a percentage of live biomass as stands age. Mortality rates in Oregon forests range from 0.5 to $2 \%$ (Turner et al., 2007; Hudiburg et al., 2009) in the absence of stand replacing disturbance. Since dynamic mortality algorithms have not been incorporated into CLM4, we chose to use $1.0 \%$ as a static mean value for the default configuration simulations. To improve on this, we parameterized CLM4 with PFT mortality rates within each ecoregion based on inventory data (Hudiburg et al., 2009). Ecoregions are areas within which ecosystems 


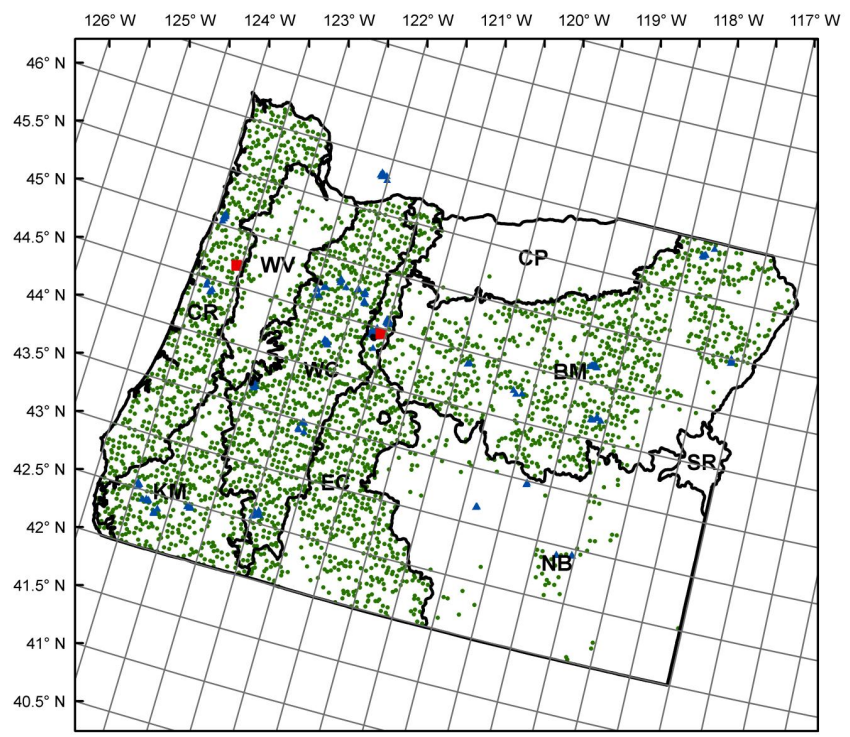

Fig. 1. Study region area (Oregon) divided by ecoregions (BM = Blue Mountains, $\mathrm{CR}=$ Coast Range, $\mathrm{CP}=$ Columbia Plateau, $\mathrm{EC}=$ East Cascades, $\mathrm{KM}=$ Klamath Mountains, $\mathrm{NB}=$ Northern Basin, $\mathrm{SR}=$ Snake River, $\mathrm{WC}=$ West Cascades, WV $=$ Willamette Valley). Green circles represent FIA plots used for evaluating annual model output, blue triangles are the supplemental plots used for parameterization, and red squares are the FLUXNET tower sites available for seasonal validation (Campbell River site in British Columbia, Canada, not shown).

(and the type, quality, and quantity of environmental resources) are generally similar (Omernik, 1987).

Offline simulations of CLM4 are typically forced with the NCEP reanalysis dataset (Qian et al., 2006) provided by NCAR. While this dataset includes the required climate and forcing variables at a sub-daily time step, the resolution $\left(\sim 2^{\circ}\right)$ is not adequate for regional simulations in Oregon. For this reason, we forced the model with a 1/8th degree regional dataset assembled by the Climate Impacts Group at the University of Washington (http://www.cses.washington. edu/data/ipccar4/) downscaled from the ECHAM5 20th century climate simulations used in the IPCC 4th assessment. The regional dataset includes daily precipitation, minimum and maximum temperature, and wind speed. Because CLM4 also requires shortwave radiation and relative humidity, we calculated values incorporating algorithms from DAYMET (Thornton et al., 1997) and methods for sub-daily calculations as described by Göeckede et al. (2010) (Appendix A).

\subsection{Model simulations and evaluation}

All model simulations are summarized in Table 2. Model spinups required $650 \mathrm{yr}$ to reach equilibrium conditions and were performed using regional physiology parameters and the downscaled climate forcing dataset (PNW). The fire module was turned "off" for spinup because in some ecoregions, biomass would "burn up" before reaching equilibrium conditions. Based on previous experience with CLM4 in the region, fire combustion estimates were reduced by $50 \%$. After spinup, control and transient simulations were run using the different model versions (see Sect. 2.6). The control simulations were run from 1850-2006 using preindustrial $\mathrm{CO}_{2}$ and $\mathrm{N}$ deposition levels (Ndep) and constant 1850 land cover. Transient simulations of each model version were run by changing $\mathrm{CO}_{2}$, nitrogen deposition, land use and land cover, and/or climate for the period from 1850-2006. Separate simulations allow for attributing the responses due to climate, land use change, and model versions. Transient $\mathrm{CO}_{2}$, Ndep, and land cover files are annual files covering the period from 1850-2006. Ndep and land cover are spatially explicit datasets interpolated from a half-degree global dataset, while the $\mathrm{CO}_{2}$ file is a single value for the entire region which changes annually. For the FLUXNET tower sites, we used the observed meteorological data for all tower site simulations including spinup. Gap-filled hourly data included air temperature, precipitation, shortwave solar radiation, wind speed, and specific humidity. Finally, the modified version of the code was used for spinup at the tower sites because the biological nitrogen fixation equation was changed for the Campbell River site (Arain et al., 2006; see Sect. 2.6).

\subsection{Observations}

We combined spatially representative observational data from 3125 FIA plots measured during 2001 to 2006 with remote sensing products on forest cover, ecoregion, and age and a global data compilation of wood decomposition data (Wirth et al., 2010) to provide current maps of the Pacific Northwest state of Oregon ( $\sim 12$ million hectares) for forest biomass carbon stocks, heterotrophic respiration, net primary production, and net ecosystem production. We included all forestland in our analysis across all age classes $(20-800 \mathrm{yr}$ old) and management regimes (Table 1). Plot values were aggregated by ecoregion, age class, and forest type and this look-up table was used to assign a value to each associated $30 \mathrm{~m}$ pixel. Methods and uncertainty of the inventory biomass and carbon flux calculations are fully described in Hudiburg et al. (2009, 2011). Tree biomass is calculated using ecoregion- and species-specific allometric equations from diameter at breast height (DBH) and height. Woody detritus length and diameter are recorded along transects for each plot in the FIA dataset. Woody detritus biomass is then calculated from piece volume and decay class density. Wood NPP is calculated using increment data from wood cores collected on the FIA plots, foliage NPP is foliage biomass divided by the average leaf retention time measured at the intensive plots, and fine root NPP is calculated from fine root biomass multiplied by the average root turnover rates from intensive plot data.

Monthly mean values of GPP from eddy covariance tower data and the associated uncertainty for the period from 
Table 1. Ecoregion and tower site characteristics in study region.

\begin{tabular}{|c|c|c|c|c|c|c|}
\hline Ecoregion & $\begin{array}{l}\text { Forest (ha) } \\
\text { (\% of Total) }\end{array}$ & $\begin{array}{l}\text { Number plots } \\
\text { private/public }\end{array}$ & $\begin{array}{l}\text { Stand age } \\
\text { private/public }\end{array}$ & Dominant forest types & $\begin{array}{r}\text { MAP } \\
\left(\mathrm{mm} \mathrm{yr}^{-1}\right)\end{array}$ & $\begin{array}{r}\text { MAT } \\
\left({ }^{\circ} \mathrm{C}\right)\end{array}$ \\
\hline Coast Range (CR) & $\begin{array}{l}2043332 \\
(17)\end{array}$ & $294 / 216$ & $34 / 75$ & $\begin{array}{l}\text { Douglas-fir, Sitka spruce, redwood, } \\
\text { western red cedar, fir-hemlock }\end{array}$ & 1742 & 11.0 \\
\hline West Cascades (WC) & $\begin{array}{l}2693263 \\
(22)\end{array}$ & $168 / 512$ & $50 / 140$ & $\begin{array}{l}\text { Douglas-fir, hemlock, mixed conifer, } \\
\text { red fir, western red cedar }\end{array}$ & 1688 & 8.8 \\
\hline $\begin{array}{l}\text { Klamath Mountains } \\
(\mathrm{KM})\end{array}$ & $\begin{array}{l}1302111 \\
(10)\end{array}$ & $121 / 192$ & $59 / 106$ & $\begin{array}{l}\text { Mixed conifer, mixed evergreen, } \\
\text { red fir, Douglas-fir, riparian, oak }\end{array}$ & 1549 & 11.5 \\
\hline $\begin{array}{l}\text { Willamette Valley } \\
\text { (WV) }\end{array}$ & $\begin{array}{l}501793 \\
(4)\end{array}$ & $93 / 17$ & $43 / 61$ & Douglas-fir, hemlock, riparian & 1280 & 11.0 \\
\hline East Cascades (EC) & $\begin{array}{l}2099866 \\
(17)\end{array}$ & $155 / 395$ & $64 / 94$ & $\begin{array}{l}\text { Ponderosa pine, mixed conifer, } \\
\text { juniper, pine, red fir }\end{array}$ & 630 & 9.1 \\
\hline Blue Mountains (BM) & $\begin{array}{l}3364151 \\
(27)\end{array}$ & $243 / 614$ & $71 / 100$ & $\begin{array}{l}\text { Mixed conifer, ponderosa pine, } \\
\text { juniper, spruce-fir }\end{array}$ & 552 & 7.3 \\
\hline Columbia Plateau (CP) & $\begin{array}{l}88922 \\
(<1)\end{array}$ & $80 / 47$ & $80 / 47$ & $\begin{array}{l}\text { Mixed conifer, ponderosa pine, } \\
\text { riparian }\end{array}$ & 330 & 9.7 \\
\hline Northern Basin (NB) & $\begin{array}{l}253690 \\
(2)\end{array}$ & $80 / 130$ & $80 / 130$ & $\begin{array}{l}\text { Juniper, aspen, pinyon-juniper, } \\
\text { ponderosa pine, mountain mahogany }\end{array}$ & 304 & 9.7 \\
\hline $\begin{array}{l}\text { Metolius Mature Site } \\
(\mathrm{me} 2)\end{array}$ & - & 1 & 80 & $\begin{array}{l}\text { Ponderosa pine (secondary growth, } \\
\text { privately owned) }\end{array}$ & 434 & 7.6 \\
\hline $\begin{array}{l}\text { Campbell River Mature } \\
\text { Site (ca1) }\end{array}$ & - & 1 & 56 & $\begin{array}{l}\text { Douglas-fir (secondary growth, } \\
\text { privately owned) }\end{array}$ & 1256 & 8.7 \\
\hline
\end{tabular}

Table 2. Regional and FLUXNET tower site simulations. Transient $\mathrm{CO}_{2}$, nitrogen deposition (Ndep), and land cover files are annual files covering the period from 1850-2006. Ndep and land cover are spatially interpolated using the CLM toolkit from a half-degree global dataset, while the $\mathrm{CO}_{2}$ file is a single value for the entire region which changes annually. Simulations marked with a * indicate tower/point simulations (ca1 $=$ Campbell River and me2 $=$ Metolius Mature Site).

\begin{tabular}{|c|c|c|c|c|c|c|c|}
\hline Name & Years & $\begin{array}{l}\text { Climate forcing } \\
\text { (Years) }\end{array}$ & $\mathrm{CO}_{2} / \mathrm{Ndep}$ & Land cover & Mortality rate & Physiology & Model \\
\hline \multicolumn{8}{|c|}{ Spinup } \\
\hline S_Oregon & 650 & PNW (1900-1949) & 1850 & 1850 & $2 \%$ & PNW & CLM4 \\
\hline S_ca $1^{*, 1,2}$ & 650 & Tower (1998-2006) & 1850 & 1850 & $1 \%$ & $\mathrm{Ca} 1$ & CLM4_stem \\
\hline S_me2* & 650 & Tower (2002-2007) & 1850 & 1850 & $1 \%$ & $\mathrm{Me} 2$ & CLM4_stem \\
\hline \multicolumn{8}{|c|}{ Control and Calibration } \\
\hline C_Default & $1850-2006$ & PNW (1900-1949) & 1850 & 1850 & $1 \%$ & PNW & CLM4 \\
\hline C_eco ${ }^{3}$ & $1850-2006$ & PNW (1900-1949) & 2000 & 2000 & Varied & PNW_eco & CLM4_eco \\
\hline C_eco_stem ${ }^{1}$ & $1850-2006$ & PNW(1900-1949) & 2000 & 2000 & Varied & PNW_eco & CLM4_stem \\
\hline \multicolumn{8}{|c|}{ Transient and Modified } \\
\hline T_PNW_default & $1850-2006$ & PNW (1900-1949; 1900-2006) & Transient & Transient & $1 \%$ & PNW & CLM4 \\
\hline T_PNW_eco ${ }^{3}$ & $1850-2006$ & PNW (1900-1949; 1900-2006) & Transient & Transient & Varied & PNW_eco & CLM4_eco \\
\hline T_PNW_eco_stem ${ }^{1}$ & $1850-2006$ & PNW (1900-1949; 1900-2006) & Transient & Transient & Varied & PNW_eco & CLM4_stem \\
\hline T_ca1* & $1850-2010$ & Tower (1998-2006) & Transient & Transient & $0.08 \%$ & Ca1 & CLM4_stem \\
\hline T_me2* & $1850-2010$ & Tower (2002-2007) & Transient & Transient & $1.0 \%$ & $\mathrm{Me} 2$ & CLM4_stem \\
\hline
\end{tabular}

1 The stem wood to leaf allocation equation was modified to change with ecoregion (location).

2 Nitrogen fixation was increased for the Campbell River site spinup and simulations.

${ }^{3}$ Physiological parameters such as foliar leaf nitrogen content were varied by species within ecoregions.

2001-2006 were downloaded from the FLUXNET database for two tower sites in the region, one in a mesic fir forest of the Coast Range ecoregion (Campbell River, BC) and one in a dry pine forest of the East Cascades (Metolius,
OR). The provided uncertainty estimates for the flux tower observations were calculated for the model-data synthesis project by Schwalm et al. (2010). These sites represent mature secondary forest under private ownership (50-80 yr) 
with contrasting rates of biomass accumulation and NPP primarily due to climatic conditions (Law et al., 2003, 2004). Seasonal patterns of modeled GPP are compared with the flux tower observations.

\subsection{Uncertainty analysis}

We calculated the total uncertainty in the current FIA estimates using the propagation of error approach (Williams et al., 2012). The propagation of error approach is a method for combining error terms to calculate total uncertainty in an estimate. Monte Carlo simulations were used to estimate the uncertainty due to variation in region- and/or species-specific allometry by using the mean and standard deviations for stem biomass and NPP calculated using three alternative sets of allometric equations. The full suite of species-specific equations that use tree diameter (i.e., DBH) and height (preferred) were compared to a DBH-only national set (Jenkins et al., 2003) and to a grouped forest type set. Total uncertainty in FIA estimates was calculated as the combined uncertainty of the allometric equations and land cover estimates (10\%) using the propagation of error approach (NRC, 2010a). Ecoregion level uncertainty estimates are represented in the figures by the gray error bars and in tables with " \pm " symbols. For finer scale evaluation (i.e., grid cell size), the uncertainty in the observations was used to evaluate model performance using the reduced chi-square $\left(x^{2}\right)$ statistic (Schwalm et al., 2010) and model bias defined as the mean of the model-data residuals for different groups of interest. Inventory plot data were grouped by ecoregion and then aggregated by precipitation regime, biome type, and age group within each ecoregion. Plots with annual precipitation greater than $800 \mathrm{~mm}$ were considered "wet" and less than $800 \mathrm{~mm}$ as "dry". FIA forest types are either evergreen needleleaf (ENF), deciduous broadleaf (DBF), or mixed ENF/DBF (MXD). Complete analysis and statistics were performed for all biomes, however since $92 \%$ of the forested area in the study region is ENF, we include only the ENF biome in the figures and tables of this document. Age groups are defined as young $(<60 \mathrm{yr})$ and mature $(>60 \mathrm{yr})$.

The reduced $x^{2}$ is the squared sum of the residuals normalized by the observation uncertainty and divided by the total number of samples (i.e., the mean $x^{2}$ for an arbitrary group of interest):

Reduced $x^{2}=\frac{1}{n} \sum_{i=1}^{n}\left(\frac{\text { Modeled }_{i}-\text { Observed }_{i}}{2 \cdot \delta_{i}}\right)^{2}$,

where, $\delta$ is the uncertainty in the $i$-th observation, "2" normalizes the uncertainty to correspond to a $95 \%$ confidence interval, and the summation is across the aggregated data groups within each ecoregion (Schwalm et al., 2010). Reduced $x^{2}$ values close to 1 indicate model-data unity or agreement. Model bias can be estimated as the mean of the residuals:

Bias $=\frac{1}{n} \sum_{i=0}^{n}\left(\right.$ Modeled $_{i}-$ Observed $\left._{i}\right)$,

where $i$ is the group of interest and positive values indicate average overestimation by the model and negative values indicate average underestimation.

\subsection{Model development}

We aimed to reduce overall uncertainty by calibrating with known regional mean values and evaluating with inventory data. This was in part due to an interest in evaluating the default model configuration with the fewest adjustments possible and utilizing the rich regional plot dataset. Testing the performance in a diverse region aids diagnosis of parameter or structural deficiencies. As stated above, the default configuration includes PFT specific physiological variables (no seasonal variation), a constant mortality rate for all forest PFTs, and a single stem wood allocation equation for all woody PFTs. After evaluation with the default configuration, we tested the use of modified model versions where the physiological parameters and mortality rates were allowed to vary by PFT within ecoregion (CLM4_eco) and where the stem wood allocation equation in addition to the physiological and mortality rates also varied by ecoregion (CLM4_stem).

For CLM4_eco and CLM4_stem, parameter values for foliar $\mathrm{C}: \mathrm{N}$ ratios, foliar $\mathrm{N}$ content in Rubisco, leaf longevity, fine root $\mathrm{C}: \mathrm{N}$ ratios, and specific leaf area were adjusted according to field plot data from sites in each of the tested ecoregions in the study area. The PFT physiological variable input file was restructured so that two PFTs were assigned to each ecoregion and surface datasets were modified to reflect the new PFT assignments (Appendix A, Tables A1 and A2). The CLM4 mortality module was then modified to assign a different mortality rate based on the PFT. For CLM4_stem, the inventory data was used to construct ecoregion-specific allocation to stem wood equations and the equations were added to the CLM4 allocation module (Appendix A, Table A4 and Fig. A1.)

Finally, CLM4 nitrogen fixation is controlled by a single equation that determines the rate as a function of NPP, yielding nitrogen fixation rates up to $1.8 \mathrm{~g} \mathrm{~N} \mathrm{~m}^{-2} \mathrm{yr}^{-1}$, whereas nitrogen fixation at the Campbell River site is reportedly $3 \mathrm{~g} \mathrm{~N} \mathrm{~m}^{-2} \mathrm{yr}^{-1}$ (Arain et al., 2006). Because this is not a parameter in the physiology file, we needed to modify the equation in the source code for the Campbell River spinup and simulations (Appendix A).

\section{Results}

\subsection{Modeled results and regional totals}

In general, CLM4_stem modeled estimates of stem biomass carbon (Fig. 2a) followed a west to east gradient with 

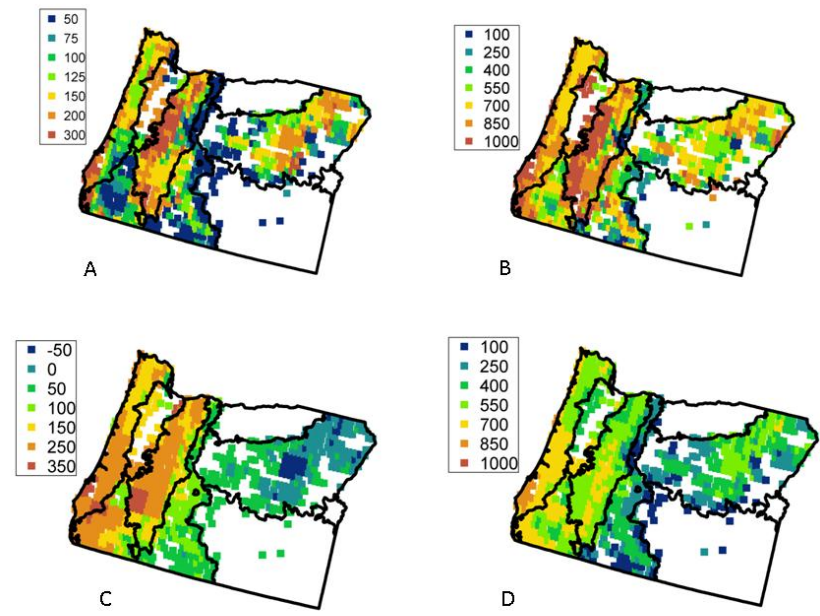

Fig. 2. Maps of modeled CLM4_stem estimates of (a) stem biomass, (b) NPP, (c) NEP, and (d) $R_{\mathrm{h}}$. Biomass is in units of $\mathrm{Mg} \mathrm{Cha}^{-1}$ and all others are in units of $\mathrm{g} \mathrm{C} \mathrm{m}^{-2} \mathrm{yr}^{-1}$. Estimates are from the "all transient" case which is representative of actual historical conditions and includes changing climate, $\mathrm{CO}_{2}$ and nitrogen deposition levels, and historical land use and land cover change.

higher values in the productive mesic western ecoregions (i.e., Coast Range, West Cascades) and lower values in the less productive dry eastern ecoregions (East Cascades, Northern Basin). Stem wood biomass peaks in the West Cascades at $360 \mathrm{MgCha}^{-1}$ and is lowest in the Northern Basin at $10 \mathrm{MgCha}^{-1}$. NPP is highest in the Coast Range with values up to $1100 \mathrm{~g} \mathrm{C} \mathrm{m}^{-2} \mathrm{yr}^{-1}$ and lowest in Northern Basin at less than $100 \mathrm{~g} \mathrm{C} \mathrm{m}^{-2} \mathrm{yr}^{-1}$ (Fig. 2b). Forest NEP ranges from $-200 \mathrm{~g} \mathrm{C} \mathrm{m}^{-2} \mathrm{yr}^{-1}$ in the Blue Mountains to $350 \mathrm{~g} \mathrm{C} \mathrm{m}^{-2} \mathrm{yr}^{-1}$ in the Coast Range (Fig. 2c), and $R_{\mathrm{h}}$ ranges from $20 \mathrm{~g} \mathrm{C} \mathrm{m}^{-2} \mathrm{yr}^{-1}$ in the Northern Basin to $750 \mathrm{~g} \mathrm{C} \mathrm{m}^{-2} \mathrm{yr}^{-1}$ in the Coast Range (Fig. 2d).

Total simulated regional tree carbon stocks are estimated to be $1.2 \mathrm{PgC}$ with $61 \%$ in the Coast Range and West Cascades alone. For the period from 2001-2006, total forest NPP and NEP averaged 57.6 and $12.7 \mathrm{Tg} \mathrm{Cyr}^{-1}$, respectively, indicating a strong sink in the region. Total modeled harvested carbon equaled 4.9 $\mathrm{Tg} \mathrm{C} \mathrm{yr}^{-1}$, and total fire emissions equaled $2.4 \mathrm{Tg} \mathrm{Cyr}^{-1}$. After accounting for these removals, the forest carbon sink (net biome production, NBP)

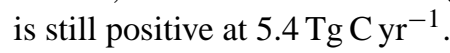

\subsection{Model improvement and testing}

We compared regional plot data of foliar chemistry and morphological characteristics with the physiological file constants used for the modeled runs. There is significant variation in both foliar carbon to nitrogen ratios and specific leaf area (projected) between ecoregions according to plot data (Fig. 3). The default configuration for CLM4 allows one foliar C : N ratio and one SLA value per PFT.
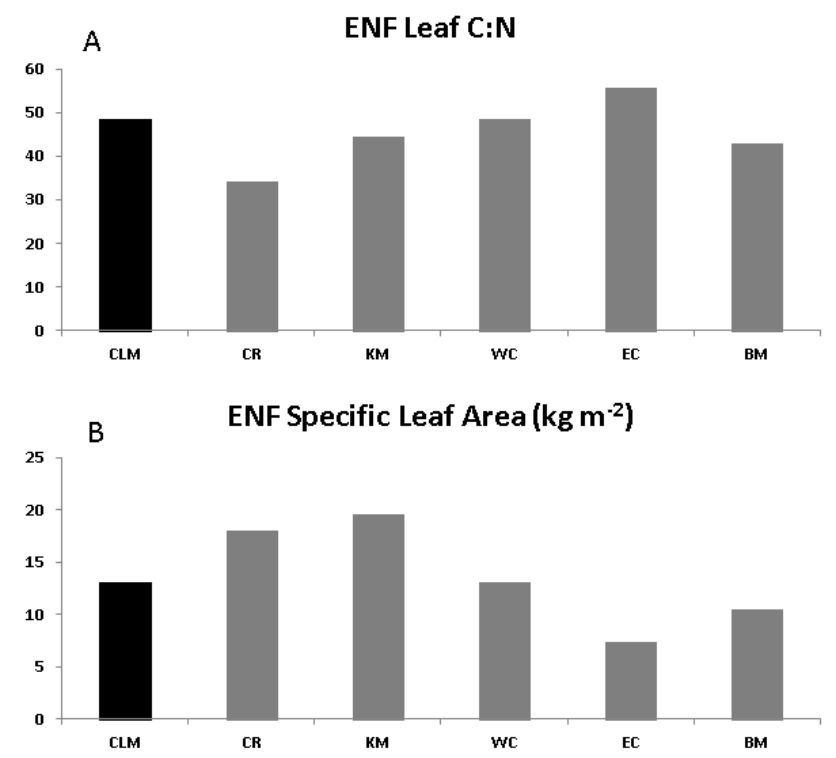

Fig. 3. Observed values for ENF leaf carbon to nitrogen ratios (A) and specific leaf area (B) from over 100 supplemental plots in the region. The black bar represents the value used for single-value per PFT parameterizations, versus the gray bars which were used for CLM4_eco and CLM4_stem simulations.

We experimented with physiological parameter spatial variation (Fig. 4; CLM4_eco), and found overall improvement with ecoregion means of NPP, but stem carbon stocks were subsequently underestimated. The default code for CLM4 includes dynamic stem wood allocation, but it is a single equation for all woody PFTs globally. Using the model version CLM4_stem, where we also changed the dynamic stem allocation equation to vary by ecoregion, we found an overall improvement in stem carbon stocks compared to CLM4.

\subsection{Spatial evaluation with inventory data}

We show ecoregion means of the evergreen needleleaf biome because it represents $92 \%$ of the forested area in the region and we do not have sufficient regional plot data for the deciduous broadleaf biome for evaluation. Before modifications, CLM4 regional modeled mean stem biomass for the period from 2001-2006 fell within the observed range of uncertainty in the Coast Range and the West Cascades, was close to observed range of uncertainty in the East Cascades and was underestimated in the Klamath Mountains (Fig. 4a; gray error bars indicate observation uncertainty). However, mean simulated biomass was twice the observed mean in the Blue Mountains. Simulated regional mean NPP was within the observed range of uncertainty in the Coast Range, East Cascades and Klamath Mountains, was slightly overestimated in the West Cascades and was again almost twice the observed mean in the Blue Mountains. After modifying the model for ecoregion differences in input physiological parameters 

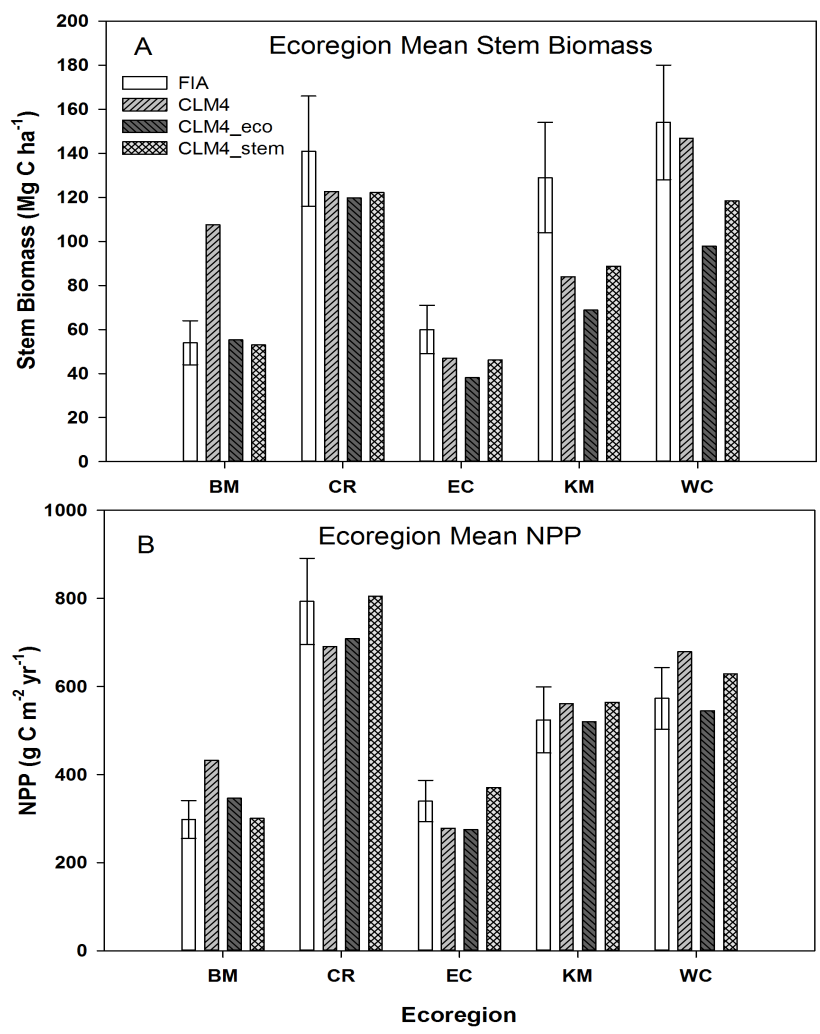

Fig. 4. Ecoregion means of modeled and observed evergreen needleleaf PFT values for the period from 2001-2006. The ENF biome covers $92 \%$ of the forested area in the study region. Bar plots show ecoregion ENF means and the associated observation uncertainty. (a) Stem biomass, and (b) NPP. Estimates are from the "all transient" case which is representative of actual historical conditions and includes changing climate, $\mathrm{CO}_{2}$ and nitrogen levels, and land use and land cover change.

(CLM4_eco), ecoregion mean stem biomass was within the observed uncertainty in the Blue Mountains, but dropped below the average in the West Cascades. Ecoregion mean NPP was within observation uncertainty in all ecoregions after modification. After modifications to the stem allocation equations, modeled ecoregion means of NPP were not significantly different from observed means (two-sided $P$ value 0.8 ), and modeled means of stem biomass fell within the observed range of uncertainty in the majority of the ecoregions.

Ecoregion means are a good first order approximation of model performance and regional total evaluation, but cannot be used to determine the dynamics that may be causing bias and reveal nothing about model fidelity at a smaller scale. Statistical tests of model performance for stem carbon biomass revealed overall better agreement with inventory data using the CLM4_stem version of the model. At $15 \mathrm{~km}$ spatial resolution, reduced $x^{2}$ statistics indicated adequate model performance for the region as a whole for both stem biomass and NPP (overall reduced $x^{2}$ was 3 and 2 , respectively). This was an improvement over the default configuration by $50 \%$ for stem biomass and $30 \%$ for NPP. Stem biomass agreement was best in the West Cascades, Blue Mountains, and Coast Range $\left(x^{2}<=2\right.$; Table 3), followed by the Klamath Mountains and East Cascades $\left(x^{2}<\right.$ 7 ). Within ecoregions, performance was generally better in older age classes (Table 3 ).

NPP also improved when using CLM4_stem, primarily because overestimation was reduced in the Blue Mountains and West Cascades (Table 3). Overestimation in the Blue Mountains exceeded $100 \mathrm{~g} \mathrm{C} \mathrm{m}^{-2} \mathrm{yr}^{-1}$ with CLM4 before modifications were made. However, reduced $x^{2}$ statistics for the Coast Range, East Cascades and Klamath Mountains did not significantly improve. As with stem biomass, there was better performance in wet versus dry stands, except in the Klamath Mountains. Performance was better for both metrics in mature stands. This was especially true for the Coast Range and West Cascades where the $x^{2}$ values for CLM4 and CLM4_stem were close to 1 for the mature age classes, indicating model-data unity.

\subsection{Evaluation with tower and supplemental plot data}

Simulated monthly values for GPP were compared with $6 \mathrm{yr}$ of eddy covariance tower data at two sites in the region. At the semi-arid mature ponderosa pine site (Metolius), a reduced $x^{2}$ value of 1.06 indicated good overall model performance (values close to 1 indicate good model performance) after accounting for observation uncertainty (Schaefer et al., 2013). Observation uncertainty ranged from 12-100\% for the Metolius site and 13-90 \% for the Campbell River site. At the semi-arid Metolius site, maximum GPP is lower for modeled results (Fig. 5a) in all years except 2003 (a particularly dry year) and 2006 (a wet year). Annual GPP was underestimated by an average of $18 \%$ (Fig. 5b). There was no noticeable bias in the fall and spring months. At the mesic mature Douglas-fir site (Campbell River), a reduced $x^{2}$ of 1.5 indicated weaker model performance than for the Metolius site, although estimates were still within the observed range of uncertainty for most months and annually (Fig. 5c and d). In contrast to the Metolius site, model data mismatch occurred primarily in spring with timing of peak GPP occurring one month early and overestimated spring values. This resulted in annual estimates that were on average $17 \%$ greater than observed GPP.

CLM4 includes direct downregulation of the photosynthetic rate under nitrogen limitation, which effectively reduces GPP. We also compared GPP before downregulation (Fig. 5a and 5b; "initial GPP") with tower data and found decreased model performance at both sites. Initial GPP was overestimated by up to $200 \mathrm{~g} \mathrm{C} \mathrm{m}^{-2}$ month $^{-1}$ at the Metolius site, especially in the late summer months. Results were similar at the Campbell River site where simulated summer maximum initial GPP was much higher than observed (Fig. 5c). 
Table 3. Stem carbon and NPP reduced $x^{2}$ statistics and model bias by ecoregion, annual precipitation regime ${ }^{\mathrm{a}}$, and age group ${ }^{\mathrm{b}}$ for CLM4 and CLM4_stem. Values marked with an * indicate good model performance $\left(x^{2}<2\right)$. Reduced $x^{2}$ values close to 1 are within observation uncertainty.

\begin{tabular}{|c|c|c|c|c|c|c|c|c|c|c|}
\hline \multicolumn{11}{|c|}{ Stem carbon: $x^{2}$ statistics } \\
\hline \multirow{3}{*}{ Ecoregion } & \multicolumn{5}{|c|}{ CLM4 simulations } & \multicolumn{5}{|c|}{ CLM4_stem simulations } \\
\hline & \multicolumn{2}{|c|}{ Precipitation } & \multicolumn{2}{|c|}{ Age group } & \multirow[b]{2}{*}{ Total } & \multicolumn{2}{|c|}{ Precipitation } & \multicolumn{2}{|c|}{ Age group } & \multirow[b]{2}{*}{ Tota } \\
\hline & Dry & Wet & Y & M & & Dry & Wet & $\mathrm{Y}$ & $\mathrm{M}$ & \\
\hline $\mathrm{CR}$ & - & 3 & 4 & $1^{*}$ & 2 & - & 3 & 4 & $1^{*}$ & 2 \\
\hline WC & 3 & 2 & 14 & 2 & 2 & 2 & $<2$ & 8 & $<2^{*}$ & $<2^{*}$ \\
\hline KM & $1^{*}$ & 8 & 2 & 8 & 7 & $1^{*}$ & 6 & $1^{*}$ & 6 & 6 \\
\hline $\mathrm{EC}$ & 5 & 6 & 15 & 5 & 4 & 5 & 5 & 14 & 5 & 4 \\
\hline $\mathrm{BM}$ & 17 & 6 & 70 & 17 & 15 & 3 & 2 & 14 & 3 & 2 \\
\hline Overall & 12 & 4 & 18 & 8 & 7 & 4 & 3 & 7 & 3 & 3 \\
\hline \multicolumn{11}{|c|}{ NPP: $x^{2}$ statistics } \\
\hline & \multicolumn{5}{|c|}{ CLM4 simulations } & \multicolumn{5}{|c|}{ CLM4_stem simulations } \\
\hline \multirow{2}{*}{ Ecoregion } & \multicolumn{2}{|c|}{ Precipitation } & \multicolumn{2}{|c|}{ Age group } & & \multicolumn{2}{|c|}{ Precipitation } & \multicolumn{2}{|c|}{ Age group } & \\
\hline & Dry & Wet & Y & M & Total & Dry & Wet & $\mathrm{Y}$ & $\mathrm{M}$ & Total \\
\hline $\mathrm{CR}$ & - & $1^{*}$ & 2 & $1^{*}$ & $1^{*}$ & - & $<2^{*}$ & 3 & $1^{*}$ & $<2^{*}$ \\
\hline WC & 3 & $1^{*}$ & 8 & $1^{*}$ & $1^{*}$ & 4 & $1^{*}$ & 6 & $1^{*}$ & $1^{*}$ \\
\hline KM & $1^{*}$ & 7 & 6 & 7 & 6 & $1^{*}$ & 7 & 6 & 6 & 5 \\
\hline $\mathrm{EC}$ & 2 & $<2^{*}$ & 8 & $<2^{*}$ & 2 & 3 & $<2^{*}$ & 14 & & 3 \\
\hline $\mathrm{BM}$ & 5 & 3 & 18 & 5 & 5 & 2 & $1^{*}$ & 8 & 2 & 2 \\
\hline Overall & 4 & 2 & 7 & 5 & 3 & 3 & 2 & 6 & 4 & 2 \\
\hline
\end{tabular}

\begin{tabular}{|c|c|c|c|c|c|c|c|c|c|c|}
\hline \multicolumn{11}{|c|}{ Stem carbon: bias } \\
\hline \multirow{3}{*}{ Ecoregion } & \multicolumn{5}{|c|}{ CLM4 simulations } & \multicolumn{5}{|c|}{ CLM4_stem simulations } \\
\hline & \multicolumn{2}{|c|}{ Precipitation } & \multicolumn{2}{|c|}{ Age group } & \multirow[b]{2}{*}{ Total } & \multicolumn{2}{|c|}{ Precipitation } & \multicolumn{2}{|c|}{ Age group } & \multirow[b]{2}{*}{ Total } \\
\hline & Dry & Wet & $\mathrm{Y}$ & M & & Dry & Wet & $\mathrm{Y}$ & $\mathrm{M}$ & \\
\hline $\mathrm{CR}$ & - & -19 & 32 & -100 & -19 & - & -17 & 36 & -100 & -17 \\
\hline WC & 13 & -11 & 74 & -40 & -9 & -7 & -37 & 45 & -65 & -36 \\
\hline $\mathrm{KM}$ & -85 & -40 & 3 & -53 & -41 & -77 & -51 & -7 & -63 & -50 \\
\hline EC & -4 & -49 & 20 & -17 & -11 & -2 & -48 & 18 & -15 & -9 \\
\hline $\mathrm{BM}$ & 54 & 2 & 77 & 45 & 48 & -4 & -36 & 21 & -11 & -7 \\
\hline Overall & 28 & -17 & 46 & -16 & 4 & -5 & -32 & 29 & -41 & -18 \\
\hline
\end{tabular}

\begin{tabular}{|c|c|c|c|c|c|c|c|c|c|c|}
\hline \multicolumn{11}{|c|}{ NPP: bias } \\
\hline \multirow{3}{*}{ Ecoregion } & \multicolumn{5}{|c|}{ CLM4 simulations } & \multicolumn{5}{|c|}{ CLM4_stem simulations } \\
\hline & \multicolumn{2}{|c|}{ Precipitation } & \multicolumn{2}{|c|}{ Age group } & \multirow[b]{2}{*}{ Total } & \multicolumn{2}{|c|}{ Precipitation } & \multicolumn{2}{|c|}{ Age group } & \multirow[b]{2}{*}{ Total } \\
\hline & Dry & Wet & $\mathrm{Y}$ & M & & Dry & Wet & $\mathrm{Y}$ & M & \\
\hline $\mathrm{CR}$ & - & -88 & -88 & -90 & -88 & & 13 & 20 & -2 & 13 \\
\hline WC & 93 & 94 & 79 & 97 & 96 & 78 & 55 & 24 & 62 & 58 \\
\hline $\mathrm{KM}$ & -221 & 105 & 22 & 92 & 85 & -140 & 93 & -4 & 85 & 81 \\
\hline $\mathrm{EC}$ & -30 & -132 & 17 & -54 & -47 & 49 & -60 & 87 & 30 & 35 \\
\hline $\mathrm{BM}$ & 133 & -66 & 149 & 104 & 112 & 17 & -128 & 40 & -6 & 2 \\
\hline Overall & 69 & 14 & 19 & 50 & 43 & 27 & 25 & 32 & 29 & 31 \\
\hline
\end{tabular}

${ }^{\mathrm{a}}$ Dry $=<800 \mathrm{~mm} \mathrm{yr}^{-1}$, Wet $=>800 \mathrm{~mm} \mathrm{yr}^{-1}$.

${ }^{\mathrm{b}} \mathrm{Y}=$ Young $<60 \mathrm{yr}, \mathrm{M}=$ Mature $>60 \mathrm{yr}$. 

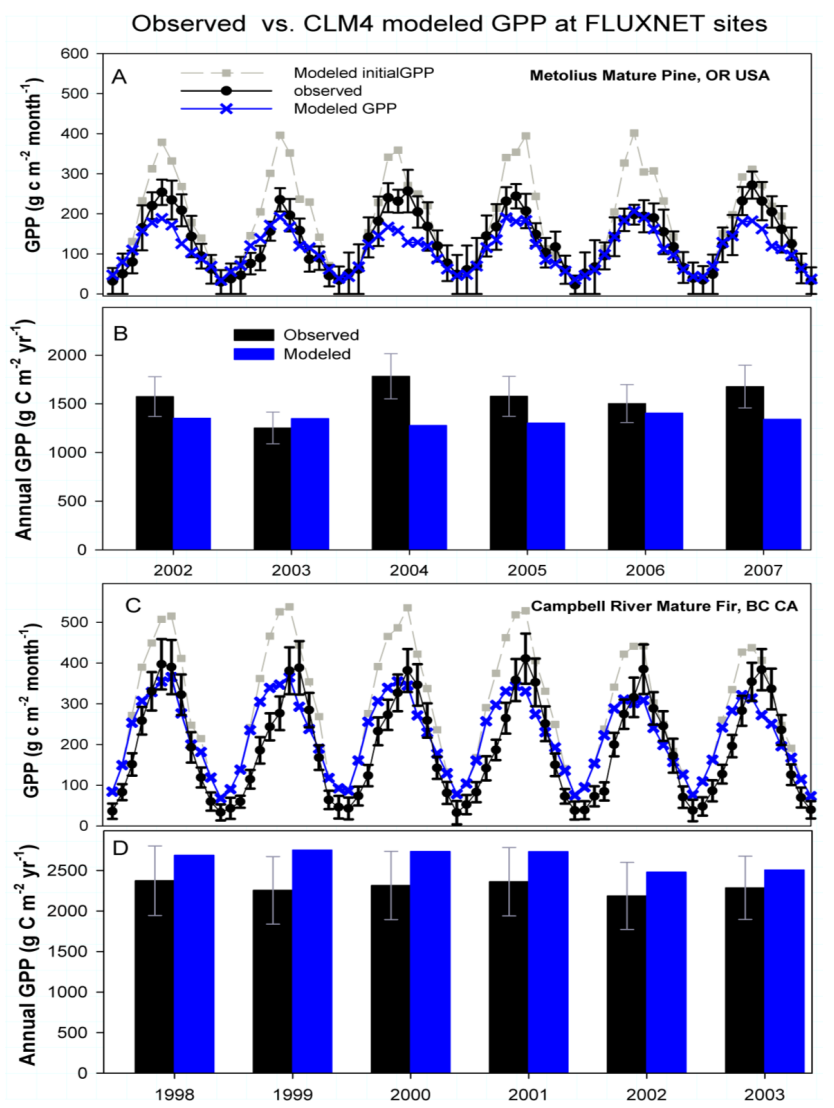

Fig. 5. Simulated monthly GPP versus observed GPP at two FLUXNET eddy covariance tower sites in the study region using the CLM_stem version of the model. Solid black circles and bars represent tower observations, gray squares are modeled values of GPP before downregulation due to nitrogen limitation, and blue crosses and bars are modeled GPP after downregulation. Black and gray error bars represent observed estimate uncertainty. (A) Monthly GPP for the years 2002-2007 at the Metolius mature pine site in Oregon, USA, (B) annual GPP at the Metolius mature pine site for 20022007, (C) monthly GPP for 1998-2003 at the Campbell River fir site, British Columbia, Canada, (D) annual GPP at the Campbell River fir site.

We compared modeled and observed monthly light use efficiency with monthly average air temperature at each tower site (Fig. 6). We define LUE as the monthly GPP as a function of monthly average incident solar radiation (shortwave radiation). At the Metolius site, observed LUE increased with air temperature to about $10^{\circ} \mathrm{C}$, then declines (Fig. 6a). In other words, higher GPP is attained at lower radiation levels at temperatures up to $10^{\circ} \mathrm{C}$. This pattern was also true for the modeled relationship, but occurred less rapidly (Fig. 6b). Simulated LUE is lower than observed LUE for lower radiation and temperature conditions, but similar to observed at higher light and temperature conditions. At the Campbell River site, there is a smaller increase in LUE with temperature than the Metolius site (Fig. 6c), and there is much
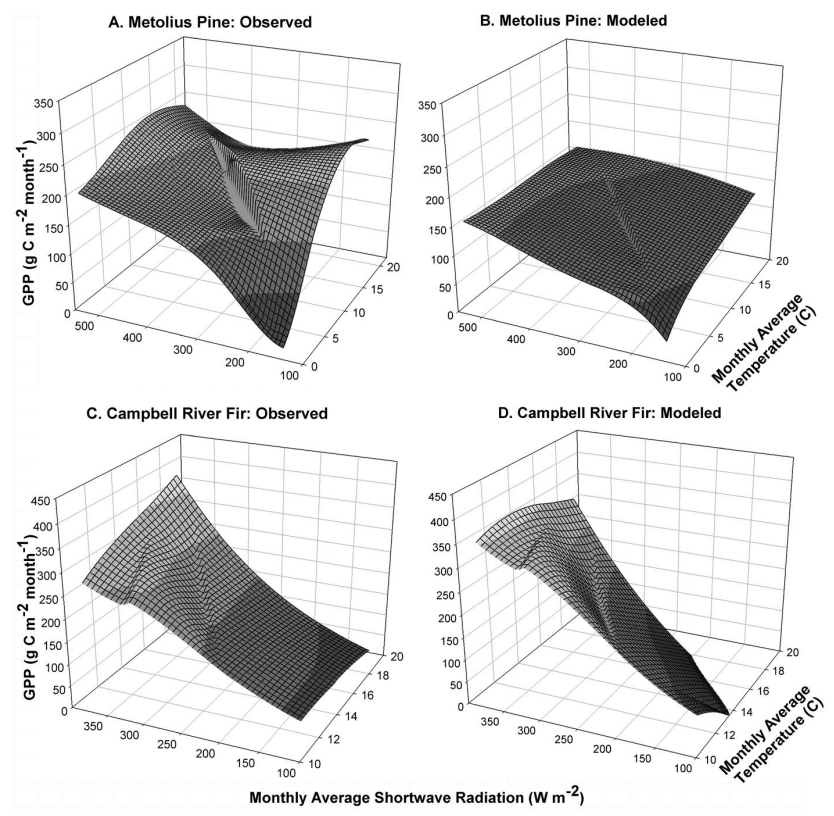

Fig. 6. 3-D surface plots of shortwave radiation versus GPP (LUE) versus monthly average temperature. (A) Observed LUE versus temperature at the Metolius site, (B) modeled LUE versus temperature at the Metolius site, (C) observed LUE versus temperature at the Campbell River site, and (D) modeled LUE versus temperature at the Campbell River site. Model results for both sites are from the CLM4_stem modified version of the model code. Model results for the Campbell River site include increased biological nitrogen fixation.

less seasonal variation in temperature. There appears to be a slight decrease in LUE with higher temperature in the modeled results (Fig. 6d), whereas there is a consistent increase with temperature in the observations. Simulated LUE is higher than observed for lower radiation and temperature conditions.

Annual biometric estimates of NPP were available from the Metolius site and are often used as cross-checks with tower data for consistency (Luyssaert et al., 2009). Modeled annual NPP was underestimated by an average of $17 \%$ when compared to biometric estimates of NPP at the Metolius site, while modeled GPP was underestimated by an average of $18 \%$ compared to the eddy covariance data. However, the ratio of NPP/GPP was nearly identical for both equaling $34 \%$ (observed) and $33 \%$ (modeled).

We also compared observed and simulated monthly GPP with growing season monthly precipitation (Fig. 7). For both sites, winter precipitation is much higher and summers are generally dry. At the Metolius site, 2002-2004 were particularly dry while 2005-2007 received average precipitation. There does not appear to be a relationship with precipitation at the mesic Campbell River site, whereas at the semiarid Metolius site, observed GPP increases for months with less than $30 \mathrm{~mm}$ of precipitation. Simulated GPP is similar 


\section{GPP vs. growing season Precipitation}

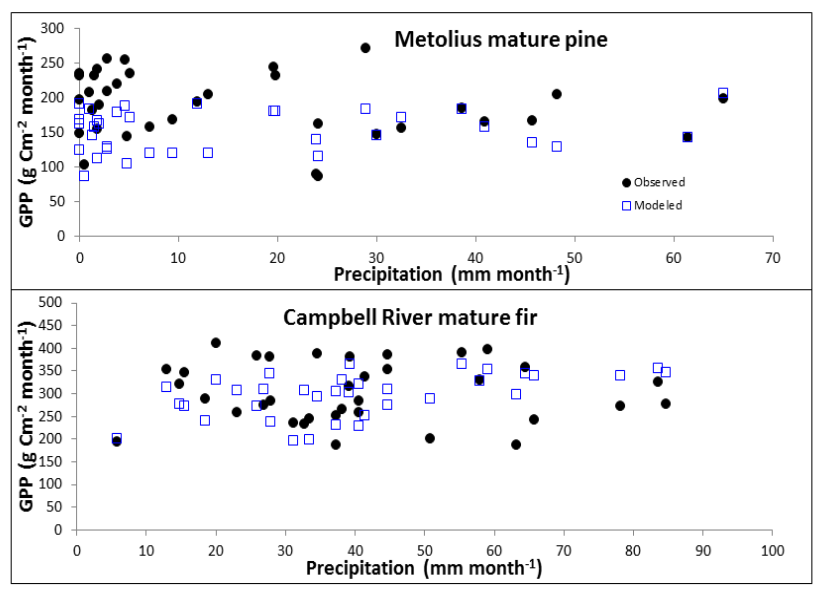

Fig. 7. GPP $\left(\mathrm{g} \mathrm{C} \mathrm{m}^{-2}\right.$ month $\left.^{-1}\right)$ versus growing season (AprilSeptember) monthly precipitation $(\mathrm{mm})$ at the FLUXNET tower sites, (A) Metolius mature pine site and (B) Campbell River mature fir site.

to observations for the higher precipitation months for both Metolius and Campbell River, but underestimated in the low precipitation months at the Metolius site.

\section{Discussion}

\subsection{Modeled results and regional totals}

Oregon is a diverse region due to the strong climatic gradient from the coast inland $(300-1800 \mathrm{~mm}$ precipitation per year) and a total of 45 associated forest types, ranging from temperate rainforests to semi-arid woodlands (Table 1). The state is divided into 8 distinct ecoregions based on climate, soil, and species characteristics, and includes a broad range of productivity, age structures, fire regimes and topography. The statewide regional patterns of carbon stocks, NPP, and NEP are similar to the observed values in this study and prior studies. Stem carbon stocks from over 8000 inventory plots and 200 plots in Oregon showed stem carbon stocks range from $60-420 \mathrm{Mg} \mathrm{Cha}^{-1}$ (Hudiburg et al., 2009) in the more mesic ecoregions (Coast Range, Klamath Mountains, West Cascades). Reported densities from the same studies for the drier ecoregions (East Cascades, Blue Mountains) range from 20 to $100 \mathrm{Mg} \mathrm{Cha}^{-1}$. The CLM4_stem estimates in this study range from $10-400 \mathrm{MgC}$ in agreement with the reported values. Pacific Northwest temperate forests have some of the highest carbon stocks in the world (Keith et al., 2009), with most of the carbon stored in the tree wood. Modeled relationships of biomass accumulation over time and with increasing age classes typically show a decrease in tree wood biomass or it reaches an asymptote. However, observations in the Oregon suggested otherwise (Hudiburg et al., 2009), and modeled allocation to wood biomass in these regions was modified in CLM4 to reflect these regional stand dynamics (CLM4_stem).

Modeled NPP ranges from $100-1100 \mathrm{~g} \mathrm{C} \mathrm{m}^{-2} \mathrm{yr}^{-1}$ (CLM4_stem) across the study region, agreeing with the reported regional values of $100-900 \mathrm{~g} \mathrm{C} \mathrm{m}^{-2} \mathrm{yr}^{-1}$ (Hudiburg et al., 2009) and falling within the range of 100 to $1600 \mathrm{~g} \mathrm{C} \mathrm{m}^{-2} \mathrm{yr}^{-1}$ reported for temperate and boreal forests (Luyssaert et al., 2008). The regional total NPP for forests is $57.6 \mathrm{Tg} \mathrm{C} \mathrm{yr}^{-1}$, a value very close to the observed total of $58.2 \times 6.5 \mathrm{Tg} \mathrm{Cyr}^{-1}$ calculated from inventory data (Law et al., 2012). The regional modeled total NEP for 2001-2006 is also close to the reported value from inventory data (12.8 versus $15.2 \pm 1.6 \mathrm{Tg} \mathrm{C} \mathrm{yr}^{-1}$; Law et al., 2012), and Biome-BGC modeled results $\left(17.0 \pm 10 \mathrm{Tg} \mathrm{C} \mathrm{yr}^{-1}\right.$; Turner et al., 2007), but lower than uncertainty of an inverse modeling estimate $\left(35.4 \mathrm{Tg} \pm 11 \mathrm{Tg} \mathrm{C} \mathrm{yr}^{-1}\right.$; Göeckede et al., 2010).

\subsection{Spatial evaluation}

After modifications were made, stem carbon stocks continued to be underestimated in all ecoregions. Performance was generally better in older age classes, and underestimation of stem biomass in old age classes was balanced by overestimation of stem biomass in young age classes in some ecoregions. Stem wood allocation is a dynamic function of the cumulative sum of annual NPP which results in different allocation ratios at different age classes. In the Pacific Northwest, the age-related biomass accumulation trajectories are known to vary by ecoregion and management regime (Van Tuyl et al., 2005; Hudiburg et al., 2009) with higher potential stem biomass in the more productive ecoregions. The variation in stem biomass within an ecoregion varies by a factor of 4 , especially in the Klamath Mountains, and capturing this type of variation would most likely require age-class dynamics be added to CLM for more than just stem wood allocation. Using existing foliage and wood NPP data computed from supplemental plots, we developed dynamic ratios of wood to foliage allocation that vary with annual NPP by ecoregion (Fig. A1). Addition of subgroups within PFTs (e.g., pines versus firs) for the ecoregions with larger variation would also improve the model results, but may not be practical for larger regions.

Implementation of ecoregion physiological variation and mortality had a significant impact on NPP performance, with better performance in mature forests for CLM4_eco and CLM4_stem. This is not surprising considering NPP tends to peak early in stand development, decline and then remain at a consistent level as stands age. The age-related variation in this response varies by ecoregion and disturbance regime (Law et al., 2004), and improvement to age-related allocation may help to correct part of the discrepancies. When using single-value parameterization of foliar $\mathrm{C}: \mathrm{N}$ ratios and specific leaf area, we found underestimation of NPP by CLM4 
in the Coast Range and overestimation in the Blue Mountains (Fig. 3), which are much higher in mesic versus semi-arid forests (Matson et al., 1994). Maximum rates of carboxylation $\left(V_{\mathrm{cmax}}\right)$ are determined by SLA and foliar nitrogen content in CLM4. Prior modeling efforts with CLM4 also found significant improvement in GPP estimates by using site-specific parameterization of $V_{\text {cmax }}$ (Bonan et al., 2011).

After implementing CLM4_eco and CLM4_stem, NPP continued to be overestimated while stem biomass continued to be underestimated in the West Cascades, although both were improved. Foliar nitrogen content in the Cascade Mountain ecoregion is lower than that of the Coast Range and Klamath Mountain ecoregions and has higher specific leaf area. The positive bias in NPP was reduced with ecoregion-specific parameterization, but this also reduced stem biomass. However, observed West Cascade stem biomass is equal to or higher than Coast Range mean biomass. Stem biomass density is affected by removal rates through fire and harvest. The regional input harvest rates in current decades match very closely with current estimates (Turner et al., 2007), but the spatial variation varies with overestimates in the West Cascades and Klamath Mountains, which could be contributing to underestimation of stem biomass overtime. Correcting the historical rates in the input file would require thorough review of historical records and is beyond the scope of this study. Fortunately, these values can be easily adjusted to the user-prescribed rates for future simulations.

Total regional modeled fire emissions are also overestimated by $1.0 \mathrm{TgC}^{-1}$ which could also be contributing to the underestimation bias. We reduced the fire woody biomass combustion coefficients in the model by $50 \%$ based on regional data (methods Sect. 2.3), but we did not change the fire prediction routine or fire burn area calculations. This is an area of research for future versions of CLM (episodic fire rather than a "slow trickle" of fire). In the meantime, we made historical comparisons of CLM4 simulated burn area (Fig. A2) with other datasets (MTBS: Eidenshank et al., 2007; and GFED: van der Werf et al., 2010) and show both over- and underestimation by CLM4_stem. The Global Fire Emissions database (GFED) underestimated burn area by $15 \%$ for the Oregon Biscuit fire in 2002 and was consistently the lowest burn area estimate compared other models in a synthesis by French et al. (2011).

Finally, nitrogen availability has recently been shown to significantly impact the NPP to GPP ratio, with higher rates of biomass production on sites with higher fertility (Vicca et al., 2012). Our results support this hypothesis, with higher biomass production in the forests with high foliar nitrogen content (Figs. 2 and 3). Thus, the model represents nitrogen influences on allocation and productivity quite well.

\subsection{Seasonal evaluation}

Simulating GPP correctly is important because most of the subsequently calculated carbon fluxes are calculated from GPP. In a model-data synthesis activity including 39 flux sites and 26 models (CLM4 was not included), GPP was generally found to be overestimated in the spring and fall and underestimated in the summer, resulting in poor model performance at most flux sites (Schaefer et al., 2013). We found CLM4 simulated GPP at the Metolius site to be close to the observed range of uncertainty (reduced $x^{2}=1.06$ ) and GPP was not over-predicted in fall and spring, resulting in overall good model performance. However, GPP was underpredicted in the summer months for some of the modeled years (Fig. 5a). LUE was determined as the primary driver of underestimation of GPP in summer months in the modeldata synthesis. Our analysis agrees with this as we found LUE to be on average less efficient in the modeled results than the observations, primarily in lower light and temperature conditions. However, this does not necessarily mean the low GPP bias in the model is caused by incorrect representation of LUE. We also found a different range of temperature thresholds for the range of LUE values, indicating PFT-specific temperature thresholds may vary, especially in the drier more extreme climates found in the eastern portion of our study region. GPP was also found to be underestimated for months with little to no precipitation (i.e., summer; Fig. 7a) indicating soil water availability or plant water use efficiency need further investigation. When we did not include nitrogen in the simulations, the "initial GPP" before downregulation occurred as a result of nitrogen limitation, leading to a positive summer bias. When nitrogen was included in the simulations, downregulation brought the majority of the simulated GPP monthly values closer to observed values, but there was too much reduction in GPP in the summer months due to nitrogen constraints.

At the Campbell River site, modeled GPP was overestimated in spring and maximum GPP was reached one month early, resulting in overall overestimation of annual GPP. Foliar nitrogen content and availability are both higher at the Campbell River site than the Metolius site, as well as precipitation. Downregulation of GPP due to nitrogen limitation does not result in underestimated summer GPP, however spring initial GPP and downregulated GPP are both too high and peak too early, indicating the $V_{\mathrm{cmax}}$ response to temperature and day length may need revising.

\subsection{Summary of results and recommendations for model improvement}

CLM4 was evaluated against inventory data in Oregon forests using the default configuration and regional parameterization. With default parameterization, initial results indicated overall underestimation of stem biomass, except in the semi-arid Blue Mountains where it was overestimated 
by $48 \mathrm{Mg} \mathrm{Cm}^{-2}$. There was good general agreement with observed NPP values. However, modeled ecoregion mean NPP was overestimated in the Blue Mountains and mesic West Cascades. Following initial default parameterization, model improvements were made to account for ecoregion differences in the physiological variables, foliar $\mathrm{N}$ content and mortality, and this resulted in an overall improvement in NPP estimates (all ecoregions fell within the observed range of uncertainty). Changing the stem wood allocation algorithm further improved the results, however wood carbon stocks were still underestimated in the West Cascades and Klamath Mountains (CLM4_stem). Increasing the number of sub-PFTs (e.g., pines, firs, and cedars) for the ecoregions with larger variation, as well as adjusting known harvest rates and improving the fire prediction and combustion algorithm, should improve results beyond what we have shown here.

Using ecoregion-specific parameterization at $15 \mathrm{~km}$ spatial resolution, reduced $x^{2}$ statistics indicated adequate model performance in all ecoregions for both stem biomass and NPP (reduced $x^{2}$ was equal 3 and 2, respectively). This was an improvement from the default configuration by $50 \%$ for stem biomass and $30 \%$ for NPP. Within ecoregions, there was good performance $\left(x^{2}<2\right)$ in the Coast Range and West Cascades. There was generally better performance in mature stands and, apart from the Klamath Mountains, better performance in wet stands.

Evaluation of CLM4 monthly GPP with eddy covariance tower data revealed good model-data agreement from July to December at the mesic site (ca1; Fig. 5c) and SeptemberMay at the semi-arid site (me2; Fig. 5a). Summer GPP was underestimated at the semi-arid site due to several possible reasons, including variation in seasonal $V_{\text {cmax }}$ response to temperature and soil water. We found a different range of temperature thresholds for the range of LUE values indicating PFT-specific temperature thresholds may vary, especially in the drier more extreme climates found in the eastern portion of our study region. At the mesic site, overestimation of spring GPP indicates that improvement to $V_{\text {cmax }}$ seasonality in CLM4 will require adjustment to other factors in addition to temperature, such as day length, in order to improve summer GPP.

This study provides a benchmark for which model evaluation and subsequent development can be used in other regions where the observations are available. There is a great need for regional assessments using land surface models with sub-grid accuracy to inform land management and policy. In order for the scientific modeling community to help inform policy and land managers about the carbon cycle implications associated with land use change, models need to be able to capture the spatial and temporal landscape variability. For example in Oregon, the variability in NPP varies tenfold across the state, within the same plant functional type. Land management policy (specifically forest) is being developed and implemented without the use of process models that account for changing climate and environmental variables as well as land use and management (e.g., harvest practices). Because CLM4 has the ability to account for these factors, it could be an especially useful tool for making predictions about land use and land cover change if model improvements were made to allow for variation within PFTs. Model structure need not substantially changed in order to do this, but simply allow for user-defined PFTs that can be scaled in quantity according to the region of interest. This would allow for less complex PFT structure in larger regions or in regions where calibration datasets are not available, but would not limit regional applications with rich datasets and more diversity. Additionally, a more dynamic PFT parameterization would also be more suitable for further development of the dynamic vegetation sub-model in CLM4.

\section{Appendix A}

\section{A1 Methods for formatting regional downscaled climate forcing dataset for use by CLM4}

The regional downscaled dataset includes daily precipitation, minimum and maximum temperature, and wind speed. To format the datasets for use by CLM4, the required shortwave radiation and relative humidity were calculated incorporating algorithms from DAYMET (Thornton et al., 1997), and methods for sub-daily calculations as described by Göeckede et al. (2010). We created hourly atmospheric forcing data files to be used in offline CLM4 simulations. Source data files are from the Climate Impacts Group (Salathe, 2008) and are downscaled historical and future ECHAM5 AR2 files specifically designed for the Pacific Northwest http: //www.cses.washington.edu/data/ipccar4/.

The specific variable calculations are as follows:

1. Air temperature: The regional input files provide daily minimum and maximum temperature. Day length was used to apply a diurnal pattern to the minimum and maximum temperatures.

2. Wind speed: The regional input files provide daily estimates of wind in $\mathrm{m} \mathrm{s}^{-1}$. Wind speed was assumed to be constant for sub-daily time steps.

3. Relative humidity: Percent relative humidity was calculated using the hourly mean temperatures calculated above and vapor pressure.

- DAYMET and MTClim algorithms were used to calculate vapor pressure from temperature, precipitation, and solar radiation. Vapor pressure was then used to calculate relative humidity (RH):

(a) $\mathrm{RH}=100 \times(\mathrm{VP} / \mathrm{SVP})$, where $\mathrm{VP}=$ the average daily vapor pressure in Pascals and $\mathrm{SVP}=$ the saturation vapor pressure. SVP varies with temperature. 
Table A1. CLM4 PFT original configuration and the new subgroup that replaced the original PFT for regional variation in CLM4_eco and CLM4_stem.

\begin{tabular}{cll}
\hline CLM PFT & Description & New PFT \\
\hline 1 & Evergreen needleleaf (temperate) & CR all, KM fir* \\
2 & Evergreen needleleaf (boreal) & WC fir \\
3 & Deciduous needleleaf (boreal) & BM all \\
4 & Evergreen broadleaf (tropical) & WC, KM pines \\
5 & Evergreen broadleaf (temperate) & No change \\
6 & Deciduous broadleaf (tropical) & EC fir \\
7 & Deciduous broadleaf (temperate) & No change \\
8 & Deciduous broadleaf (boreal) & EC pines \\
9 & Evergreen broadleaf shrub & No change \\
10 & Deciduous broadleaf shrub (temperate) & No change \\
\hline
\end{tabular}

* Fir includes Douglas-fir and true firs.

(b) $\mathrm{SVP}=610.78 \times \exp (T /(T+238.3) \times 17.2694)$, where $T$ is the current temperature in ${ }^{\circ} \mathrm{C}$.

4. Precipitation: The input files provide daily sums of precipitation. This needed to be distributed over the day, but not evenly. CLM will evaporate off the water too quickly and none of it will reach the plant roots. The precipitation was split into 3 equal amounts of precipitation and dropped at $8 \mathrm{~h}$ intervals, similar to the NCEP dataset where it is dropped at $6 \mathrm{~h}$ intervals. We recognize that more sophisticated diurnal precipitation algorithms using site observations could be developed, but more locations with sub-daily patterns of rainfall would be necessary for the region.

5. FSDS (incoming shortwave radiation or incident solar): This variable is not provided in the input files. Again, DAYMET algorithms were used. The inputs required are daily minimum and maximum temperature, precipitation, latitude, longitude, and elevation, all of which are available from the downscaled regional dataset.

\section{A2 Methods for making PFT modifications in CLM4}

There are 17 PFTs in CLM4, eight of which are forested. Because we did not need the tropical or boreal PFTs, we reorganized the PFT physiological file to represent the variation between and within the temperate evergreen needleleaf PFT among the ecoregions. The old and new PFT assignments are shown in Tables A1 and A2. We also show the parameters that varied for each new PFT. The surface datasets and the dynamic PFT file were altered to match the new PFT assignments. Inventory and remote sensing data were used to identify within region PFT percentage cover for "fir" versus "pine", where necessary. The FLUXNET tower sites were also parameterized using site-specific observations and regional observations where site-specific observations were not available. Tower physiological parameterizations are in Table A3.

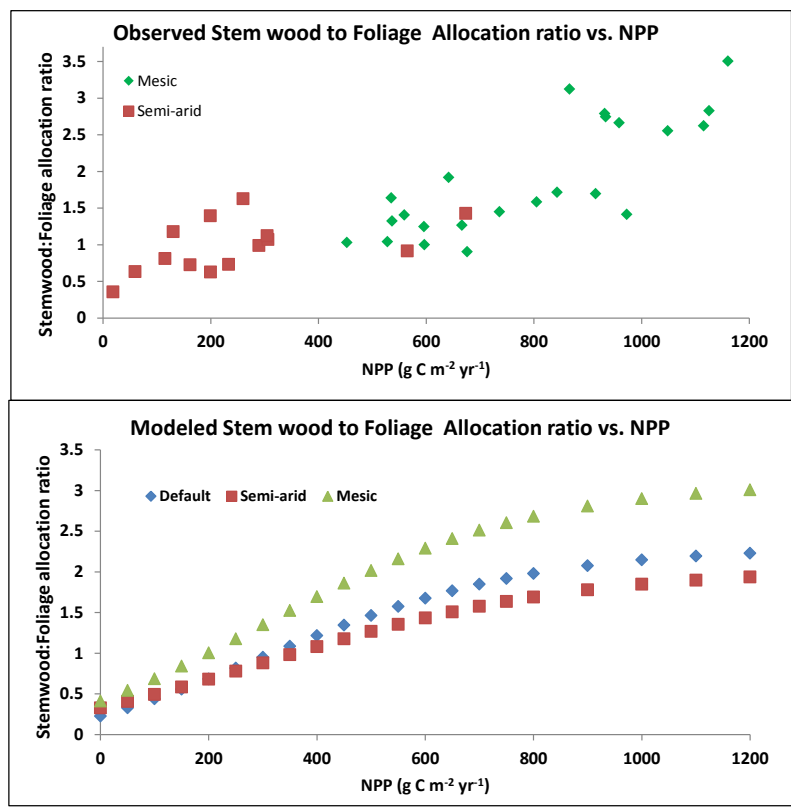

Fig. A1. (a) Supplemental plot ratio of annual stem wood production to foliage production versus annual NPP for the mesic sites (green) and semi-arid (red), (b) equations representing allocation to stem wood production versus foliage production as a function of annual NPP. The default CLM4 equation is blue and the modified equations are for mesic (green) and semi-arid (red).

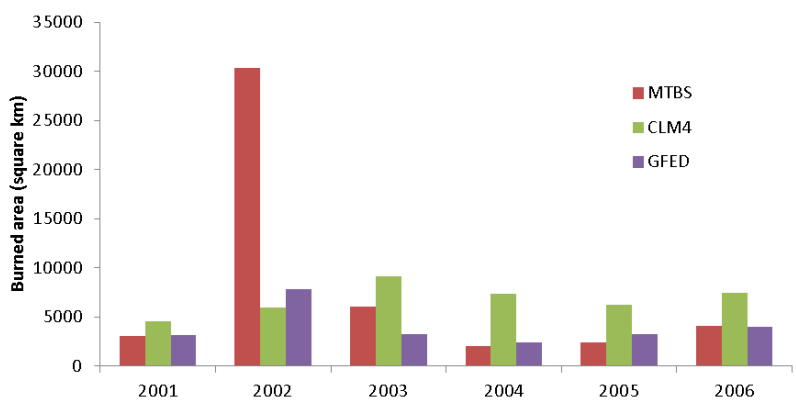

Fig. A2. Historical annual area burned in Oregon (km-2). Estimates are from the Monitoring Trends in Burn Severity database (Eidenshink et al. 2007), the Global Fire Emissions Database (van der Werf et al. 2010), and CLM4. CLM4 overestimates burn area in Oregon for all years except for 2002 compared to the remote sensing-based estimates. CLM4 does not include a fire suppression algorithm, which could be contributing to the high bias. However, burn area estimates do not exceed more than $2 \%$ of the land area for any year. GFED estimates are known to be the lowest for burn area compared to other models (French et al., 2011).

\section{A3 Methods for stem allocation modification in CLM4}

The PFT physiology file includes an option to have the fraction of annual NPP allocated to stem wood versus foliage change with the increasing annual sum of NPP throughout the year. The equation is for all forested PFTs: 
Table A2. Model physiological parameters that vary for subgroups of PFTs in each ecoregion.

\begin{tabular}{lccccc}
\hline $\begin{array}{l}\text { New PFT } \\
\text { (PFT number) }\end{array}$ & $\begin{array}{c}\text { Specific leaf } \\
\text { area (SLA; } \\
\left.\mathrm{m}^{-2} \mathrm{~g}^{-1} \mathrm{C}\right)\end{array}$ & $\begin{array}{c}\text { Foliar } \\
\mathrm{C}: \mathrm{N} \\
\text { ratio }\end{array}$ & $\begin{array}{c}\text { Foliar \% } \\
\text { leaf N in } \\
\text { Rubisco }\end{array}$ & $\begin{array}{c}\text { Leaf } \\
\text { longevity }\end{array}$ & $\begin{array}{c}\text { Mortality } \\
\text { rate (\%) }\end{array}$ \\
\hline CR all, KM fir (1) & 0.013 & 35 & 5.0 & 5 & 0.8 \\
WC fir (2) & 0.013 & 48 & 5.0 & 5 & 1.0 \\
BM all (3) & 0.007 & 55 & 3.5 & 3 & 1.3 \\
WC, KM pine (4) & 0.009 & 50 & 3.7 & 3 & 1.0 \\
EC fir (6) & 0.010 & 43 & 3.7 & 5 & 0.8 \\
EC pine (8) & 0.007 & 56 & 3.7 & 3 & 1.0 \\
\hline
\end{tabular}

Table A3. Model physiological parameters that varied from the CLM4 default parameter values for the Metolius mature pine and the Campbell River mature fir FLUXNET sites.

\begin{tabular}{lrrrrrr}
\hline $\begin{array}{l}\text { New PFT } \\
\text { (PFT number) }\end{array}$ & $\begin{array}{r}\text { Specific leaf } \\
\text { area (SLA; } \\
\left.\mathrm{m}^{-2} \mathrm{~g}^{-1} \mathrm{C}\right)\end{array}$ & $\begin{array}{r}\text { Foliar } \\
\mathrm{C}: \mathrm{N} \\
\text { ratio }\end{array}$ & $\begin{array}{r}\text { Foliar \% } \\
\text { leaf N in } \\
\text { Rubisco }\end{array}$ & $\begin{array}{r}\text { Leaf } \\
\text { longevity }\end{array}$ & $\begin{array}{r}\text { Fine root: } \\
\text { leaf } \\
\text { allocation }\end{array}$ & $\begin{array}{r}\text { Mortality } \\
\text { rate }(\%)\end{array}$ \\
\hline Metolius (me2) & 0.009 & 50 & 5.0 & 4 & 1.2 & 0.8 \\
Campbell River (ca1) & 0.013 & 32 & 10.0 & 5 & 1.0 & 1.0 \\
\hline
\end{tabular}

Table A4. Stem wood allocation equations for each ecoregion PFT. The equation was only varied for ecoregions where stem wood was significantly over- or underestimated. Maximum allocation is the upper limit of annual NPP that will be allocated to stem wood production versus foliage production.

\begin{tabular}{|c|c|c|}
\hline $\begin{array}{l}\text { New PFT } \\
\text { (PFT number) }\end{array}$ & Allocation equation & $\begin{array}{c}\text { Maximum } \\
\text { allocation }\end{array}$ \\
\hline CR all, KM fir (1) & $3.5 /(1.0+\exp (-0.004 \times($ annsum_npp $(t)-300.0)))-0.4$ & 3.0 \\
\hline WC fir (2) & $3.5 /(1.0+\exp (-0.004 \times($ annsum_npp $(t)-300.0)))-0.4$ & 3.0 \\
\hline BM all (3) & $2.3 /(1.0+\exp (-0.0035 \times($ annsum_npp $(t)-300.0)))-0.27$ & 1.7 \\
\hline WC, KM pine (4) & $2.7 /\left(1.0+\exp \left(-0.004 \times\left(\operatorname{annsum} \_n p p(t)-300.0\right)\right)\right)-0.4$ & 2.2 \\
\hline EC fir $(6)$ & $3.5 /\left(1.0+\exp \left(-0.004 \times\left(\operatorname{annsum} \_n p p(t)-300.0\right)\right)\right)-0.4$ & 3.0 \\
\hline EC pine (8) & $2.7 /\left(1.0+\exp \left(-0.004 \times\left(\operatorname{annsum} \_n p p(t)-300.0\right)\right)\right)-0.4$ & 2.2 \\
\hline
\end{tabular}

Allocation ratio

$=\left(2.7 /\left(1.0+\exp \left(-0.004 \times\left(\operatorname{annsum} \_n p p(t)-300.0\right)\right)\right)\right)-0.4$

where "annsum_npp" is the total PFT NPP summed over the year at the current time step $(t)$. The ratio is constrained to be 0.20 when NPP $=0$ and does not exceed 2.2 for NPP values greater than $1000 \mathrm{~g} \mathrm{C} \mathrm{m}^{-2} \mathrm{yr}^{-1}$. Using supplemental plot data, we found annual stem wood to foliage NPP allocation ratios as high as 3.7 for the mesic ecoregions and no higher than 2.0 for the semi-arid ecoregions (Fig. A1a). We were unable to investigate seasonal allocation ratios with the plot data. We modified the equation to increase allocation to stem wood versus foliage as stands age in the mesic ecoregions compared to the default equation and decrease allocation to stem wood versus foliage in the semi-arid ecoregions compared to the default equation (Fig. A1b and Table A4).

\section{A4 Methods for biological nitrogen fixation modification in CLM4}

Biological nitrogen fixation in CLM4 is a dynamic equation based on the annual sum of NPP and is updated on an annual time step. The equation is for all PFTs (not PFT dependent):

Nitrogen fixation $\left(\mathrm{g} \mathrm{N} \mathrm{m}^{-2} \mathrm{yr}^{-1}\right)$

$=(1.8 \times(1.0--\exp (-0.003 \times \mathrm{NPP})))$

where NPP is the annual sum of net primary production, and the function represents smaller increases in biological nitrogen fixation at higher levels of NPP to incorporate the hypothesis that $\mathrm{N}$ fixation is eventually limited by other nutrients such as phosphorus. Maximum fixation rates do not exceed $1.8 \mathrm{~g} \mathrm{~N} \mathrm{~m}^{-2} \mathrm{yr}^{-1}$. The Campbell River fir site reports rates of $3 \mathrm{~g} \mathrm{~N} \mathrm{~m}^{-2} \mathrm{yr}^{-1}$ (Arain et al., 2006). Pacific Northwest forests have reported additions of up to $15 \mathrm{~g}$ of $\mathrm{N} \mathrm{m}^{-2} \mathrm{yr}^{-1}$ from native symbiotic nitrogen fixing plant species which became established on cut or burned forested 
areas (Cleveland et al., 1999). However, the abundance and distribution of these species is limited to early successional forests following disturbance and would be difficult to predict by both ecoregion and plant functional type for the regional simulations. Because we knew the exact disturbance history and the reported rate for the Campbell River mature fir site (ca1) we modified the equation to yield up to $2.5 \mathrm{~g} \mathrm{~N} \mathrm{~m}^{-2} \mathrm{yr}^{-1}$, retaining the limitation by other nutrients:

ca1 Nitrogen fixation $\left(\mathrm{g} \mathrm{N} \mathrm{m}^{-2} \mathrm{yr}^{-1}\right)$

$=(2.5 \times(1.0-\exp (-0.006 \times \mathrm{NPP})))$

where the rate yields higher rates of fixation for lower values of annual NPP than the original equation to better represent successional dynamics.

Acknowledgements. This research was performed under an appointment to the Global Change Education Program administered by the Oak Ridge Institute for Science and Education, under contract between the US Department of Energy and Oak Ridge Associated Universities and the Environmental Research Terrestrial Carbon Program (Award \# DE-FG02-04ER64361). We would like to thank J. Martin for data contribution, the FLUXNET database, and A. Black for use of the Campbell River site data.

Edited by: P. Stoy

\section{References}

Arain, M. A., Yuan, F., and Andrew Black, T.: Soil-plant nitrogen cycling modulated carbon exchanges in a western temperate conifer forest in Canada, Agr. Forest Meteorol., 140, 171-192, doi:10.1016/j.agrformet.2006.03.021, 2006.

Bonan, G. B., Lawrence, P. J., Oleson, K. W., Levis, S., Jung, M., Reichstein, M., Lawrence, D. M., and Swenson, S. C.: Improving canopy processes in the Community Land Model version 4 (CLM4) using global flux fields empirically inferred from FLUXNET data, J. Geophys. Res., 116, G02014, doi:10.1029/2010JG001593, 2011.

Bonan, G. B., Oleson, K. W., Fisher, R. A., Lasslop, G., and Reichstein, M.: Reconciling leaf physiological traits and canopy flux data: Use of the TRY and FLUXNET databases in the Community Land Model version 4, J. Geophys. Res., 117, G02026, doi:10.1029/2011JG001913, 2012.

Cleveland, C. C., Townsend, A. R., Schimel, D. S., Fisher, H., Howarth, R. W., Hedin, L. O., Perakis, S. S., Latty, E. F., Von Fischer, J. C., Elseroad, A., and Wasson, M. F.: Global patterns of terrestrial biological nitrogen $\left(\mathrm{N}_{2}\right)$ fixation in natural ecosystems, Global Biogeochem. Cy., 13, 623-645, doi:10.1029/1999gb900014, 1999.

Eidenshink, J., Schwind, B., Brewer, K., Zhu, Z. L., Quayle, B., and Howard, S.: A project for monitoring trends in burn severity, Fire Ecol., 3, 3-20, 2007.

Farquhar, G. D., von Caemmerer, S., and Berry, J.: A biochemical model of photosynthetic $\mathrm{CO}_{2}$ assimilation in leaves of $\mathrm{C}_{3}$ species, Planta, 149, 78-90, 1980.

French, N. H. F., de Groot,W. J., Jenkins, L. K., Rogers, B. M., Alvarado, E., Amiro, B., de Jong, B., Goetz, S., Hoy, E., Hyer, E.,
Keane, R., Law, B. E., McKenzie, D., McNulty, S. G., Ottmar, R., Pérez-Salicrup, D. R., Randerson, J., Robertson, K. M., and Turetsky, M.: Model comparisons for estimating carbon emissions from North American wildland fire, J. Geophys. Res., 116, G00K05, doi:10.1029/2010JG001469, 2011.

Göeckede, M., Michalak, A. M., Vickers, D., Turner, D. P., and Law, B. E.: Atmospheric inverse modeling to constrain regional-scale $\mathrm{CO}_{2}$ budgets at high spatial and temporal resolution, J. Geophys. Res., 115, D15113, doi:10.1029/2009JD012257, 2010.

Groenendijk, M., Dolman, A. J., Ammann, C., Arneth, A., Cescatti, A., Dragoni, D., Gash, J. H. C., Gianelle, D., Gioli, B., Kiely, G., Knohl, A., Law, B. E., Lund, M., Marcolla, B., van der Molen, M. K., Montagnani, L., Moors, E., Richardson, A. D., Roupsard, O., Verbeeck, H., and Wohlfahrt, G.: Seasonal variation of photosynthetic model parameters and leaf area index from global Fluxnet eddy covariance data, J. Geophys. Res., 116, G04027, doi:10.1029/2011JG001742, 2012a.

Groenendijk, M., Dolman, A. J., van der Molen, M. K., Leuning, R., Arneth, A., Delpierre, N., Gash, J. H. C., Lindroth, A., Richardson, A. D., Verbeeck, H., and Wohlfahrt, G.: Assessing parameter variability in a photosynthesis model within and between plant functional types using global Fluxnet eddy covariance data, Agr. Forest Meteorol., 151, 22-38, 2012b.

Harmon, M. E., Ferrell, W. K., and Franklin, J. F.: Effects on carbon storage of conversion of old-growth forests to young forests, Science, 247, 699-702, doi:10.1126/science.247.4943.699, 1990.

Hudiburg, T., Law, B. E., Turner, D. P., Campbell, J., Donato, D., and Duane, M.: Carbon dynamics of Oregon and Northern California forests and potential land-based carbon storage, Ecol. Appl., 19, 163-180, 2009.

Hudiburg, T. W., Law, B. E., Wirth, C., and Luyssaert, S.: Regional carbon dioxide implications of forest bioenergy production, Nat. Clim. Change, 1, 419-423, 2011.

Hurtt, G. C., Frolking, S., Fearon, M. G., Moore, B., Shevliakova, E., Malyshev, S., Pacala, S. W., and Houghton, R. A.: The underpinnings of land-use history: three centuries of global gridded land-use transitions, wood-harvest activity, and resulting secondary lands, Glob. Change Biol., 12, 1208-1229, 2006.

IPCC: IPCC expert meeting report: Technical Summary, Towards new scenarios for analysis of emissions, climate change, impacts, and response strategies, Intergovernmental Panel on Climate Change, Cambridge, 2007.

Jenkins, J. C., Chojnacky, D. C., Heath, L. S., and Birdsey, R. A.: National-Scale Biomass Estimators for United States Tree Species, Forest Sci., 49, 12-35, 2003.

Keith, H., Mackey, B. G., and Lindenmayer, D. B.: Re-evaluation of forest biomass carbon stocks and lessons from the world's most carbon-dense forests, P. Natl. Acad. Sci. USA, 106, 1163511640, doi:10.1073/pnas.0901970106, 2009.

Krishnan, P., Black, T. A., Jassal, R. S., Chen, B., and Nesic, Z.: Interannual variability of the carbon balance of three different-aged Douglas-fir stands in the Pacific Northwest, J. Geophys. Res., 114, G04011, doi:10.1029/2008JG000912, 2009.

Law, B. E., Sun, O. J., Campbell, J., Van Tuyl, S., and Thornton, P. E.: Changes in carbon storage and fluxes in a chronosequence of ponderosa pine, Glob. Change Biol., 9, 510-524, 2003.

Law, B. E., Turner, D., Campbell, J., Sun, O. J., Van Tuyl, S., Ritts, W. D., and Cohen, W. B.: Disturbance and climate effects on carbon stocks and fluxes across Western Oregon USA, Glob. 
Change Biol., 10, 1429-1444, 2004.

Law, B., Hudiburg, T., and Luyssaert, S Thinning effects on forest productivity: consequences of preserving old forests and mitigating impacts of fire and drought, Plant Ecol. Divers., doi:10.1080/17550874.2012.679013, 2012.

Lawrence, D., Oleson, K. W., Flanner, M. G., Thorton, P. E., Swenson, S. C., Lawrence, P. J., Zeng, X., Yang, Z.-L., Levis, S., Skaguchi, K., Bonan, G. B., and Slater, A. G.: Parameterization Improvements and Functional and Structural Advances in Version 4 of the Community Land Model, J. Adv. Model. Earth Syst., 3, M03001, doi:10.1029/2011MS000045, 2011a.

Lawrence, D. M., Oleson, K. W., Flanner, M. G., Fletcher, C. G., Lawrence, P. J., Levis, S., Swenson, S. C., and Bonan, G. B.: The CCSM4 land simulation, 1850-2005: Assessment of surface climate and new capabilities, J. Climate, 25, 2240-2260, doi:10.1175/JCLI-D-11-00103.1, $2011 \mathrm{~b}$.

Luyssaert, S., Schulze, E. D., Borner, A., Knohl, A., Hessenmoller, D., Law, B. E., Ciais, P., and Grace, J.: Old-growth forests as global carbon sinks, Nature, 455, 213-215, 2008.

Luyssaert, S., Reichstein, M., Schulze, E.-D., Janssens, I. A., Law, B. E., Papale, D., Dragoni, D., Goulden, M., Granier, A., Kutsch, W. L., Linder, S., Moors, E., Munger, J. W., Pilegaard, K., Saunders, M., and Falge, E. M.: Towards a consistency cross-check of eddy covariance flux based and biometric estimates of ecosystem carbon balance, Global Biogeochem. Cy., 23, GB3009, doi:10.1029/2008GB003377, 2009.

Matson, P., Johnson, L., Billow, C., Miller, J., and Pu, R.: Seasonal Patterns and Remote Spectral Estimation of Canopy Chemistry Across the Oregon Transect, Ecol. Appl., 4, 280-298, 1994.

Moss, R. H., Edmonds, J. A., Hibbard, K. A., Manning, M. R., Rose, S. K., van Vuuren, D. P., Carter, T. R., Emori, S., Kainuma, M., Kram, T., Meehl, G. A., Mitchell, J. F. B., Nakicenovic, N., Riahi, K., Smith, S. J., Stouffer, R. J., Thomson, A. M., Weyant, J. P., and Wilbanks, T. J.: The next generation of scenarios for climate change research and assessment, Nature, 463, 747-756, 2010.

NRC: Verifying Greenhouse Gas Emissions Methods to Support International Climate Agreements, edited by: Pacala, S. W., National Academies Press, Washington DC, 2010a.

Oleson, K. W., Lawrence, D. M., Bonan, G. B., Flanner, M. G., Kluzek, E., Lawrence, P. J., Levis, S., Swenson, S. C., Thornton, P. E., Dai, A., Decker, M., Dickinson, R., Feddema, J., Heald, C. L., Hoffman, F., Lamarque, J. F., Mahowald, N., Niu, G.-Y., Qian, T., Randerson, J., Running, S., Sakaguchi, K., Slater, A., Stockli, R., Wang, A., Yang, Z.-L., and Zeng, X.: Technical Description of version 4.0 of the Community Land Model (CLM), National Center for Atmospheric Research Boulder, CO, 257, 2010.

Omernik, J. M.: Ecoregions of the conterminous United States, Map (scale 1:7,500,000), Ann. Assoc. Am. Geogr., 77, 118-125, 1987.

Pacala, S. W.: Verifying Greenhouse Gas Emissions: Methods to Support International Climate Agreements, NRC, The National Academies Press, Washington DC, 2010.

Qian, T., Dai, A., Trenberth, K. E., and Oleson, K. W.: Simulation of Global Land Surface Conditions from 1948 to 2004, Part I: Forcing Data and Evaluations, J. Hydrometeorol., 7, 953-975, 2006.

Salathe, E. P., Mote, P. W., and Wiley, M. W.: Review of scenario selection and downscaling methods for the assessment of climate change impacts on hydrology in the United States pacific northwest, Int. J. Climatol., 27, 1611-1621, 2007.

Salathé, E., Leung, L., Qian, Y., and Zhang, Y.: Regional climate model projections for the State of Washington, Climatic Change, 102, 51-75, 2010.

Schaefer, K., Schwalm, C. R., Williams, C., Arain, M. A., Barr, A., Chen, J. M., Davis, K. J., Dimitrov, D., Hilton, T. W., Hollinger, D. Y., Humphreys, E., Poulter, B., Raczka, B. M., Richardson, A. D., Sahoo, A., Thornton, P., Vargas, R., Verbeeck, H., Anderson, R., Baker, I., Black, T. A., Bolstad, P., Chen, J., Curtis, P. S., Desai, A. R., Dietze, M., Dragoni, D., Gough, C., Grant, R.F., Gu, L., Jain, A., Kucharik, C., Law, B., Liu, S., Lokipitiya, E., Margolis, H. A., Matamala, R., McCaughey, J. H., Monson, R., Munger, J. W., Oechel, W., Peng, C., Price, D.T., Ricciuto, D., Riley, W. J., Roulet, N., Tian, H., Tonitto, C., Torn, M., Weng, E., and Zhou, $\mathrm{X}$.: A model-data comparison of gross primary productivity: Results from the North American Carbon Program site synthesis, J. Geophys. Res., 117, in press, doi:10.1029/2012jg001960, 2013.

Schwalm, C. R., Williams, C. A., Schaefer, K., Anderson, R., Arain, M. A., Baker, I., Barr, A., Black, T. A., Chen, G., Chen, J. M., Ciais, P., Davis, K. J., Desai, A., Dietze, M., Dragoni, D., Fischer, M. L., Flanagan, L. B., Grant, R., Gu, L., Hollinger, D., Izaurralde, R. C., Kucharik, C., Lafleur, P., Law, B. E., Li, L., Li, Z., Liu, S., Lokupitiya, E., Luo, Y., Ma, S., Margolis, H., Matamala, R., McCaughey, H., Monson, R. K., Oechel, W. C., Peng, C., Poulter, B., Price, D. T., Riciutto, D. M., Riley, W., Sahoo, A. K., Sprintsin, M., Sun, J., Tian, H., Tonitto, C., Verbeeck, H., and Verma, S. B.: A model-data intercomparison of $\mathrm{CO}_{2}$ exchange across North America: Results from the North American Carbon Program site synthesis, J. Geophys. Res., 115, G00H05, doi:10.1029/2009JG001229, 2010.

Thomas, C. K., Law, B. E., Irvine, J., Martin, J. G., Pettijohn, J. C., and Davis, K. J.: Seasonal hydrology explains interannual and seasonal variation in carbon and water exchange in a semiarid mature ponderosa pine forest in central Oregon, J. Geophys. Res., 114, G04006, doi:10.1029/2009JG001010, 2009.

Thornton, P. E. and Zimmermann, N. E.: An improved canopy integration scheme for a land surface model with prognostic canopy structure, J. Climate, 20, 3902-3923, 2007.

Thornton, P. E., Running, S. W., and White, M. A.: Generating surfaces of daily meteorological variables over large regions of complex terrain, J. Hydrol., 190, 214-251, 1997.

Turner, D. P., Ritts, W. D., Law, B. E., Cohen, W. B., Yang, Z., Hudiburg, T., Campbell, J. L., and Duane, M.: Scaling net ecosystem production and net biome production over a heterogeneous region in the western United States, Biogeosciences, 4, 597-612, doi:10.5194/bg-4-597-2007, 2007.

van der Werf, G. R., Randerson, J. T., Giglio, L., Collatz, G. J., Mu, M., Kasibhatla, P. S., Morton, D. C., DeFries, R. S., Jin, Y., and van Leeuwen, T. T.: Global fire emissions and the contribution of deforestation, savanna, forest, agricultural, and peat fires (19972009), Atmos. Chem. Phys., 10, 11707-11735, doi:10.5194/acp10-11707-2010, 2010.

Van Tuyl, S., Law, B. E., Turner, D. P., and Gitelman, A. I.: Variability in net primary production and carbon storage in biomass across Oregon forests-an assessment integrating data from forest inventories, intensive sites, and remote sensing, Forest Ecol. Manag., 209, 273-291, 2005. 
Vicca, S., Luyssaert, S., Peñuelas, J., Campioli, M., Chapin, F. S., Ciais, P., Heinemeyer, A., Högberg, P., Kutsch, W. L., Law, B. E., Malhi, Y., Papale, D., Piao, S. L., Reichstein, M., Schulze, E. D., and Janssens, I. A.: Fertile forests produce biomass more efficiently, Ecol. Lett., 15, 520-526, 2012.
White, M. A., Thornton, P. E., Running, S. W., and Nemani, R. R.: Parameterization and Sensitivity Analysis of the BIOME-BGC Terrestrial Ecosystem Model: Net Primary Production Controls, Earth Interact., 4, 1-85, 2000. 